\title{
Ti Group Metallocene-Catalyzed Synthesis of 1-Hexene Dimers and Tetramers
}

\author{
Pavel V. Kovyazin, Almira Kh. Bikmeeva, Denis N. Islamov (D, Vasiliy M. Yanybin, Tatyana V. Tyumkina \\ and Lyudmila V. Parfenova *(i)
}

Citation: Kovyazin, P.V.; Bikmeeva, A.K.; Islamov, D.N.; Yanybin, V.M.; Tyumkina, T.V.; Parfenova, L.V. Ti Group Metallocene-Catalyzed Synthesis of 1-Hexene Dimers and Tetramers. Molecules 2021, 26, 2775. https://doi.org/10.3390/ molecules26092775

Academic Editor: Andrea Rossin

Received: 10 April 2021

Accepted: 4 May 2021

Published: 8 May 2021

Publisher's Note: MDPI stays neutral with regard to jurisdictional claims in published maps and institutional affiliations.

Copyright: (c) 2021 by the authors. Licensee MDPI, Basel, Switzerland. This article is an open access article distributed under the terms and conditions of the Creative Commons Attribution (CC BY) license (https:/ / creativecommons.org/licenses/by/ $4.0 /)$.
Institute of Petrochemistry and Catalysis of Russian Academy of Sciences, Prospekt Oktyabrya, 141, 450075 Ufa, Russia; kpv38@mail.ru (P.V.K.); almira.bikmeeva@gmail.com (A.K.B.); islamov19@gmail.com (D.N.I.); vyanybin@gmail.com (V.M.Y.); ttvnmr@gmail.com (T.V.T.)

* Correspondence: luda_parfenova@ipc-ras.ru; Tel.: +7-347-284-3527

\begin{abstract}
Hexene transformations in the catalytic systems $\mathrm{L}_{2} \mathrm{MCl}_{2}-\mathrm{XAlBu}^{\mathrm{i}}{ }_{2}(\mathrm{~L}=\mathrm{Cp}, \mathrm{M}=\mathrm{Ti}, \mathrm{Zr}, \mathrm{Hf}$; $\left.\mathrm{L}=\mathrm{Ind}, \mathrm{rac}-\mathrm{H}_{4} \mathrm{C}_{2}[\mathrm{THInd}]_{2}, \mathrm{M}=\mathrm{Zr} ; \mathrm{X}=\mathrm{H}, \mathrm{Bu}^{\mathrm{i}}\right)$ and $\left[\mathrm{Cp}_{2} \mathrm{ZrH}_{2}\right]_{2}-\mathrm{ClAlR}_{2}$ activated by MMAO-12, $\mathrm{B}\left(\mathrm{C}_{6} \mathrm{~F}_{5}\right)_{3}$, or $\left(\mathrm{Ph}_{3} \mathrm{C}\right)\left[\mathrm{B}\left(\mathrm{C}_{6} \mathrm{~F}_{5}\right)_{4}\right]$ in chlorinated solvents $\left(\mathrm{CH}_{2} \mathrm{Cl}_{2}, \mathrm{CHCl}_{3}, \mathrm{o}-\mathrm{Cl}_{2} \mathrm{C}_{6} \mathrm{H}_{4}, \mathrm{ClCH}_{2} \mathrm{CH}_{2} \mathrm{Cl}\right)$ were studied. The systems $\left[\mathrm{Cp}_{2} \mathrm{ZrH}_{2}\right]_{2}-\mathrm{MMAO}-12$, $\left[\mathrm{Cp}_{2} \mathrm{ZrH}_{2}\right]_{2}-\mathrm{ClAlBu}{ }_{2}{ }_{2}-\mathrm{MMAO}-12$, or $\mathrm{Cp}_{2} \mathrm{ZrCl}_{2}-$ $\mathrm{HAlBu}_{2}{ }_{2}$-MMAO-12 $\left(\mathrm{B}\left(\mathrm{C}_{6} \mathrm{~F}_{5}\right)_{3}\right)$ in $\mathrm{CH}_{2} \mathrm{Cl}_{2}$ showed the highest activity and selectivity towards the formation of vinylidene head-to-tail alkene dimers. The use of chloroform as a solvent provides further in situ dimer dimerization to give a tetramer yield of up to $89 \%$. A study of the reaction of $\left[\mathrm{Cp}_{2} \mathrm{ZrH}_{2}\right]_{2}$ or $\mathrm{Cp}_{2} \mathrm{ZrCl}_{2}$ with organoaluminum compounds and MMAO-12 by NMR spectroscopy confirmed the formation of $\mathrm{Zr}, \mathrm{Zr}$-hydride clusters as key intermediates of the alkene dimerization. The probable structure of the $\mathrm{Zr}, \mathrm{Zr}$-hydride clusters and ways of their generation in the catalytic systems were analyzed using a quantum chemical approach (DFT).
\end{abstract}

Keywords: metallocenes; metal hydrides; dimerization; nuclear magnetic resonance; density functional theory

\section{Introduction}

Alkene dimers and oligomers represent a large class of compounds that are used as comonomers in ethylene polymerization and as raw materials for the production of adhesives, surfactants, fragrances, synthetic lubricating fuel additives, etc. [1-6]. The following industrial processes have been successfully developed and implemented for the production of olefin oligomers: (i) oligomerization of ethylene in the presence of triethylaluminum with subsequent oxidation to higher alcohols (Ziegler-Alfol process), (ii) Philips process of ethylene oligo-and polymerization on chromium catalysts, (iii) Ni-catalyzed synthesis of linear $\alpha$-olefins via ethylene oligomerization (shell higher olefin process (SHOP)), (iv) oligomerization of ethylene to linear C4-C10 olefins by $\alpha$-select technology (Axens) or $\alpha$-SABLIN technology (Sabic and Linde) [7]. Currently, some research groups are developing strategies for the production of highly efficient jet and diesel fuels via oligomerization of alkenes (1-butene, 1-hexene) synthesized from renewable plant raw materials $[2,8]$.

Among the catalysts, Ti group metallocene complexes showed high efficiency in alkene di-, oligo-, and polymerization [9-12]. In this way, the process of zirconocene-catalyzed dimerization of terminal alkenes to give products with a vinylidene moiety $>\mathrm{C}=\mathrm{CH}_{2}$ is well-known (Scheme 1) [5,6,13-20]. 


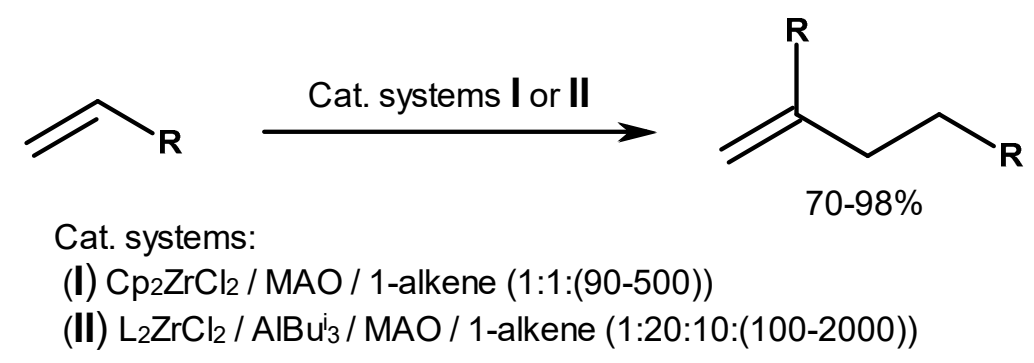

Scheme 1. Zirconocene-catalyzed dimerization of terminal alkenes.

Despite significant progress in this area, the mechanism of the dimerization reaction is not fully understood. Earlier, the hypothesis on the key role of the hydride cation $\left[\mathrm{Cp}_{2} \mathrm{ZrH}\right]^{+}$ was put forward [14]. Subsequently, it was postulated that bimetallic hydride complexes $\mathrm{L}_{2} \mathrm{Zr}(\mu-\mathrm{H})_{3} \mathrm{AlR}_{2}$ can act as catalytically active species in the alkene dimerization [21,22]. Recently, we studied the systems $\mathrm{Cp}_{2} \mathrm{ZrCl}_{2}-\mathrm{XAlBu}_{2}{ }_{2}\left(\mathrm{X}=\mathrm{H}, \mathrm{Bu}{ }^{\mathrm{i}}\right)$ and $\left[\mathrm{Cp}_{2} \mathrm{ZrH}_{2}\right]_{2}-\mathrm{ClAlR}_{2}(\mathrm{R}$ $=\mathrm{Me}, \mathrm{Et}, \mathrm{Bu}^{\mathrm{i}}$ ) activated by MMAO-12 (modified methylaluminoxane) or organoboron compounds and found new biszirconium hydride intermediates $\left(\mathrm{Cp}_{2} \mathrm{ZrH}_{2} \cdot \mathrm{Cp}_{2} \mathrm{ZrHCl} \cdot \mathrm{ClAlR} 2\right)$, which provide selective formation of head-to-tail dimerization products $[19,20,23]$. However, the questions on the possible structure of the key intermediates and their formation in the catalytic systems remain open.

Thus, our work was aimed at investigating the effect of transition metal $\eta^{5}$-complexes and solvents (chlorine-containing solvents) on the activity, chemo- and regioselectivity of the systems $\mathrm{L}_{2} \mathrm{MCl}_{2}-\mathrm{XAlBu}_{2}{ }_{2}\left(\mathrm{~L}=\mathrm{Cp}, \mathrm{M}=\mathrm{Ti}, \mathrm{Zr}, \mathrm{Hf} ; \mathrm{L}=\mathrm{Ind}\right.$, rac- $\mathrm{H}_{4} \mathrm{C}_{2}[\mathrm{THInd}]_{2}, \mathrm{M}=\mathrm{Zr}$; $\left.\mathrm{X}=\mathrm{H}, \mathrm{Bu}{ }^{\mathrm{i}}\right)$ and $\left[\mathrm{Cp}_{2} \mathrm{ZrH}_{2}\right]_{2}-\mathrm{ClAlR}_{2}$ activated by MMAO-12, $\mathrm{B}\left(\mathrm{C}_{6} \mathrm{~F}_{5}\right)_{3}$, or $\left(\mathrm{Ph}_{3} \mathrm{C}\right)\left[\mathrm{B}\left(\mathrm{C}_{6} \mathrm{~F}_{5}\right)_{4}\right]$ in alkene oligomerization. NMR studies and quantum chemical calculations were applied to establish the possible structure of the hydride intermediates formed in these systems. The results showed that the M,M-type bimetallic hydrides and their action mechanisms are unique for the dimerization reaction.

\section{Results and Discussion}

2.1. Transformations of 1-Hexene with $\mathrm{Cp}_{2} \mathrm{MY}_{2}(\mathrm{M}=\mathrm{Ti}, \mathrm{Zr}, \mathrm{Hf} ; \mathrm{Y}=\mathrm{H}, \mathrm{Cl})-\mathrm{XAlBu^{i }}{ }_{2}\left(\mathrm{X}=\mathrm{H}, \mathrm{Bu}{ }^{i}\right)$ Catalytic Systems Activated by MMAO-12, $B\left(\mathrm{C}_{6} \mathrm{~F}_{5}\right)_{3}$, or $\left(\mathrm{Ph}_{3} \mathrm{C}\right)\left[\mathrm{B}\left(\mathrm{C}_{6} \mathrm{~F}_{5}\right)_{4}\right]$

The conditions for the selective synthesis of vinylidene dimers in the presence of catalytic systems $\mathrm{Cp}_{2} \mathrm{ZrY}_{2}(\mathrm{Y}=\mathrm{H}, \mathrm{Cl})-\mathrm{XAlBu}_{2}{ }_{2}\left(\mathrm{X}=\mathrm{H}, \mathrm{Bu}^{\mathrm{i}}\right)$-activator (Scheme 2, catalytic systems $\mathbf{A}$ and $\mathbf{B})$, developed in our previous study, were taken as the starting point for the experiment (Table 1, entry 1) [19,20].

The reaction proceeds in toluene or benzene at $20-60{ }^{\circ} \mathrm{C}$ to give the target products in $81-98 \%$ yields within 5 to $150 \mathrm{~min}$, depending on the type of activator (Table 1, entries $1,15,21,27$, and 43). The use of chlorine-containing solvents in these systems was found to accelerate the reaction. For example, the system $\left[\mathrm{Cp}_{2} \mathrm{ZrH}_{2}\right]_{2}-\mathrm{ClAlBu}{ }_{2}{ }_{2}-\mathrm{MMAO}-12$ with a molar ratio [Zr]:[Al]:[MMAO-12]:[1-hexene] $=1: 3: 30: 400$ at a temperature of $40{ }^{\circ} \mathrm{C}$ in $\mathrm{CH}_{2} \mathrm{Cl}_{2}$ gives 1-hexene dimer in a yield of more than $98 \%$ by the 15 th minute of the reaction (Table 1, entry 2). When the reaction is carried out in chloroform, the relative content of dimers decreases to $92 \%$ (entry 4 ). Under the same conditions, the dimers produced in the first minutes of the reaction serve as substrates for the subsequent dimerization to afford dimers of dimer 7 in 75-79\% yields in $180 \mathrm{~min}$ (entries 7, 8, Figures S26 and S27). According to ${ }^{1} \mathrm{H}$ and ${ }^{13} \mathrm{C}$ NMR data, the structures of these products correspond to those proposed earlier [16,22,24-26]. Dimerization of 5 occurs probably via participation of cationic species formed upon the reaction of $\mathrm{CHCl}_{3}$ with $\mathrm{ClAlR}_{2}$ or MMAO-12. 


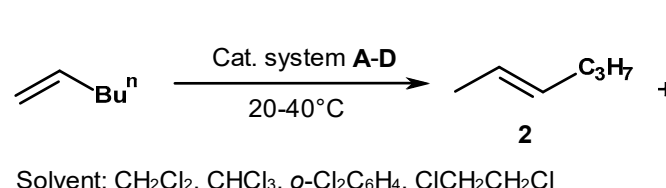

Solvent: $\mathrm{CH}_{2} \mathrm{Cl}_{2}, \mathrm{CHCl}_{3}, \mathrm{o}-\mathrm{Cl}_{2} \mathrm{C}_{6} \mathrm{H}_{4}, \mathrm{ClCH}_{2} \mathrm{CH}_{2} \mathrm{Cl}$
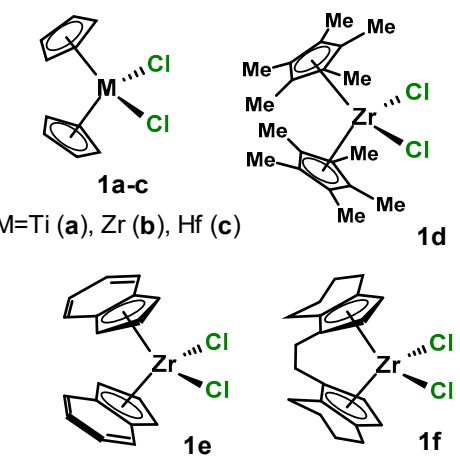

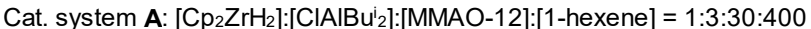

Cat. system $\mathrm{B}:\left[\mathrm{Cp}_{2} \mathrm{ZrH}_{2}\right]:\left[\mathrm{CIAIBu}_{2}{ }_{2}\right]:\left[\mathrm{B}\left(\mathrm{C}_{6} \mathrm{~F}_{5}\right)_{3}\right.$ or $\left.\left(\mathrm{Ph}_{3} \mathrm{C}\right)\left[\mathrm{B}\left(\mathrm{C}_{6} \mathrm{~F}_{5}\right)_{4}\right]\right]:[1$-hexene $]=4: 16: 1: 400$

Cat. system C: [ $\left.\mathrm{L}_{2} \mathrm{MCl}_{2}\right]:\left[\mathrm{HAIBu}{ }_{2}\right]:[\mathrm{MMAO}-12]:[1-$ hexene] $=1: 3:(10-30):(400-1000)$

Cat. system D: $\left[\mathrm{Cp}_{2} \mathrm{MCl}_{2}\right]:\left[\mathrm{HAIBu}{ }_{2}\right]:\left[\mathrm{B}\left(\mathrm{C}_{6} \mathrm{~F}_{5}\right)_{3}\right.$ or $\left.\left(\mathrm{Ph}_{3} \mathrm{C}\right)\left[\mathrm{B}\left(\mathrm{C}_{6} \mathrm{~F}_{5}\right)_{4}\right]\right]:[1-$ hexene $]=(2-4):(10-16): 1:(800-1000)$



$\downarrow$ in situ<smiles>CC(Br)(CCBr)CC(Br)=CCBr</smiles><smiles>CC(Br)(CCBr)CCBr</smiles><smiles>CC(Br)(CCBr)CC(=C[Pb])CCBr</smiles>

7

Scheme 2. 1-Hexene dimerization and oligomerization in catalytic systems A-D.

The replacement of MMAO- 12 by $\mathrm{B}\left(\mathrm{C}_{6} \mathrm{~F}_{5}\right)_{3}$ in the system $\left[\mathrm{Cp}_{2} \mathrm{ZrH}_{2}\right]_{2}-\mathrm{ClAlBu}^{\mathrm{i}}{ }_{2}-$ activator leads to a significant reduction in substrate conversion. The reaction occurs only in chloroform, and the conversion of 1-hexene in $16 \mathrm{~h}$ is $75 \%$ with a $71 \%$ content of dimers in the product mixture (entries 18, 19). Unlike $\mathrm{B}\left(\mathrm{C}_{6} \mathrm{~F}_{5}\right)_{3}$, compound $\left(\mathrm{Ph}_{3} \mathrm{C}\right)\left[\mathrm{B}\left(\mathrm{C}_{6} \mathrm{~F}_{5}\right)_{4}\right]$ can activate the system $\left[\mathrm{Cp}_{2} \mathrm{ZrH}_{2}\right]_{2}-\mathrm{ClAlBu}{ }_{2}{ }_{2}$. Under these conditions, the conversion of 1-hexene in $3 \mathrm{~h}$ was higher in $\mathrm{CH}_{2} \mathrm{Cl}_{2}(99 \%$, entry 26$)$, and the reaction predominantly gave tetramer 7 in $69 \%$ yield. In contrast, in chloroform, the 1-hexene conversion was $81 \%$ in $16 \mathrm{~h}$, and oligomeric products 6 , including compound 7 , prevailed in the product mixture (entries 24, 25).

The use of chlorine-containing solvents $\mathrm{CH}_{2} \mathrm{Cl}_{2}$ and $\mathrm{CHCl}_{3}$ in the case of the system [Cp $\left.\mathrm{ZrH}_{2}\right]_{2}-\mathrm{MMAO}-12$ at the ratio [Zr]:[MMAO-12]:[1-hexene] $=1: 30: 400$ allows the reaction to be carried out in the absence of $\mathrm{ClAlR}_{2}$ with a $>99 \%$ conversion of 1-hexene and up to $89-91 \%$ yield of dimer 5 (entries 9, 10). In $o$-dichlorobenzene and 1,2-dichloroethane, the reaction proceeds to a lower substrate conversion and a lower yield of the dimeric product (entries 11-14). The composition of the reaction products formed in the system $\left[\mathrm{Cp}_{2} \mathrm{ZrH}_{2}\right]_{2}-\mathrm{MMAO}-12-1-$ hexene for $16 \mathrm{~h}$ in any of the solvents $\left(\mathrm{CH}_{2} \mathrm{Cl}_{2}, \mathrm{CHCl}_{3}, 0-\mathrm{Cl}_{2} \mathrm{C}_{6} \mathrm{H}_{4}\right.$, $\mathrm{ClCH}_{2} \mathrm{CH}_{2} \mathrm{Cl}$ ) did not change significantly. Attempts to activate $\left[\mathrm{Cp}_{2} \mathrm{ZrH}_{2}\right]_{2}$ with boroncontaining activators in the absence of ClAlR 2 were unsuccessful (entries 16, 17, 22, 23).

Thus, vinylidene dimer 5 is formed in a high yield and with high selectivity under the action of $\left[\mathrm{Cp}_{2} \mathrm{ZrH}_{2}\right]_{2}-\mathrm{ClAlBu}{ }_{2}{ }_{2}-\mathrm{MMAO}-12$ or $\left[\mathrm{Cp}_{2} \mathrm{ZrH}_{2}\right]_{2}-\mathrm{MMAO}-12$ in $\mathrm{CH}_{2} \mathrm{Cl}_{2}$. Chloroform facilitates the formation of a non-classical tetramer of 1-hexene (7), which could be used as a component of lubricants [16,24-26].

The catalytic system based on $\mathrm{Cp}_{2} \mathrm{ZrCl}_{2}, \mathrm{HAlBu}_{2}{ }_{2}$, and MMAO-12 also provides

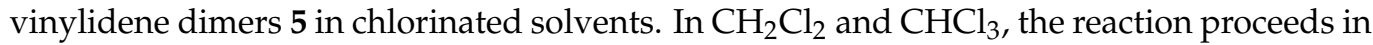
30 min with the conversion of 1-hexene above $99 \%$ and the yield of dimers of $98 \%$ (entries $28,34)$. Increasing 1-hexene initial concentration to 1000 equivalents leads to decreased alkene conversion to $82 \%$ and the yield of dimeric product to $80 \%$ in $\mathrm{CH}_{2} \mathrm{Cl}_{2}$. Under these conditions, the conversion and the yield of dimers are higher in $\mathrm{CHCl}_{3}$ than in $\mathrm{CH}_{2} \mathrm{Cl}_{2}$ and amount to $>99 \%$ and $90-98 \%$ in $30 \mathrm{~min}$, respectively (entries 32,35 ). 
Table 1. Catalytic activity and chemoselectivity of systems $\mathbf{A}$ and $\mathbf{B}$ in the reaction with 1-hexene.

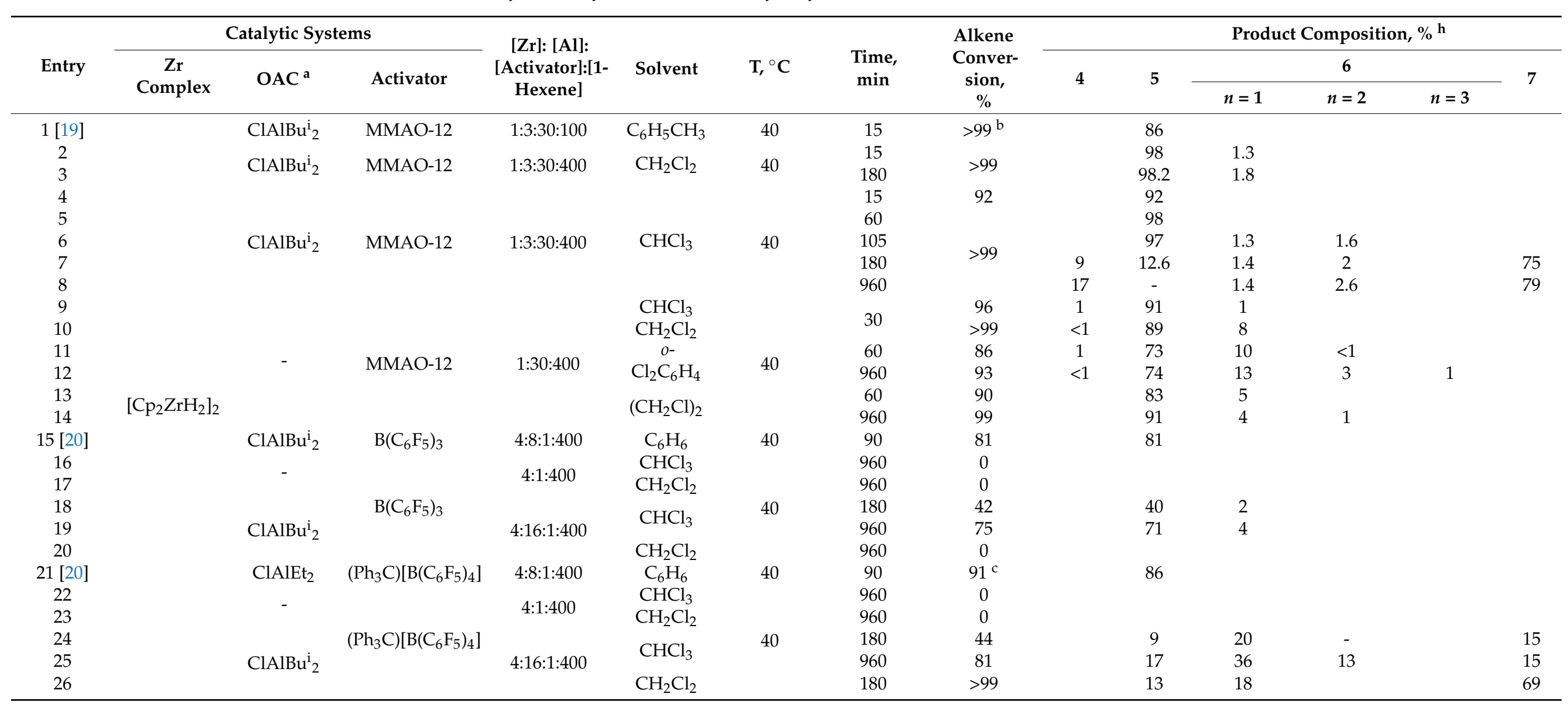


Table 1. Cont.

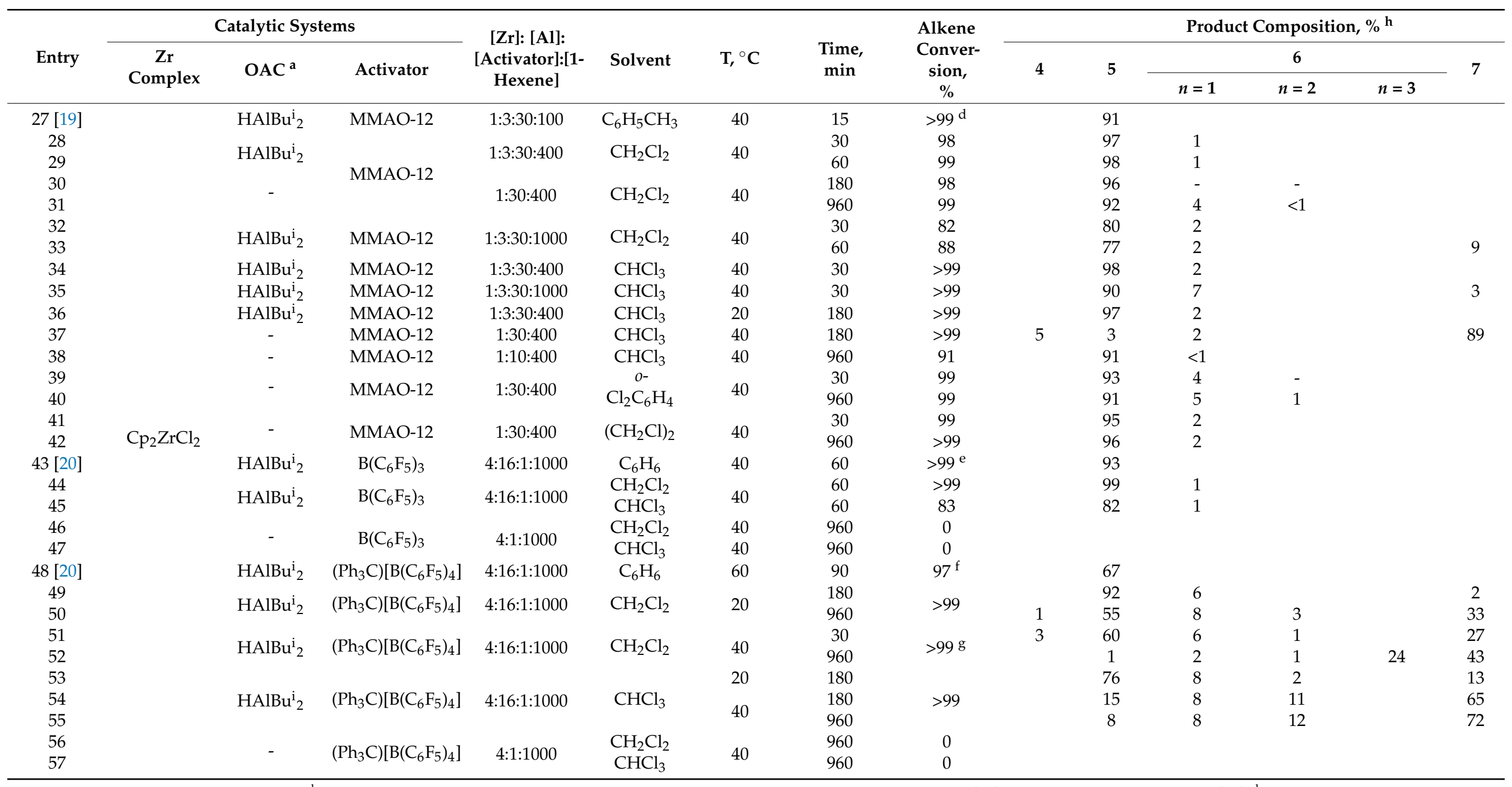

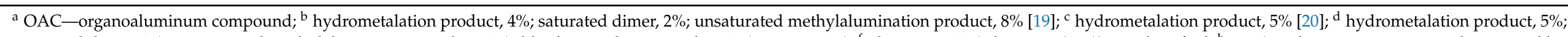

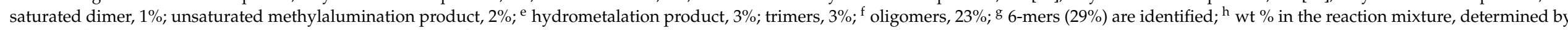
GC-MS of deuterolysis or hydrolysis products (the details of the GC-MS analysis is shown in Supporting Information, Figures S28 and S29). 
The reaction carried out in the presence of $\mathrm{Cp}_{2} \mathrm{ZrCl}_{2}$ and MMAO-12 at the ratio $[\mathrm{Zr}]$ : [MMAO-12]:[1-hexene] = 1:30:400 in chlorinated solvents $\left(\mathrm{CH}_{2} \mathrm{Cl}_{2}, o-\mathrm{Cl}_{2} \mathrm{C}_{6} \mathrm{H}_{4}, \mathrm{ClCH}_{2} \mathrm{CH}_{2} \mathrm{Cl}\right)$ at $40{ }^{\circ} \mathrm{C}$ results in $91-96 \%$ yield of dimers (entries 30, 31, 39-42). Carrying out the reaction in chloroform gives dimers of dimer 7 in a yield of up to $89 \%$ (entry 37). A decrease in the relative amount of MMAO-12 in the system to [Zr]:[MMAO-12]:[1-hexene] = 1:10:400 provides the selective formation of dimerization products at the level of $91 \%$ within $16 \mathrm{~h}$.

The highest yield of dimer 5 at the level of $99 \%$ is achieved by using a neutral boroncontaining activator $\mathrm{B}\left(\mathrm{C}_{6} \mathrm{~F}_{5}\right)_{3}$ in the system $\mathrm{Cp}_{2} \mathrm{ZrCl}_{2}-\mathrm{HAlBu}_{2}{ }_{2}$ at the ratio $[\mathrm{Zr}]:[\mathrm{Al}]:\left[\mathrm{B}\left(\mathrm{C}_{6} \mathrm{~F}_{5}\right)_{3}\right]$ : [1-hexene] $=4: 16: 1: 1000$ and in dichloromethane as a solvent (entry 44).

Activation of system $\mathrm{Cp}_{2} \mathrm{ZrCl}_{2}-\mathrm{HAlBu}_{2}{ }_{2}$ by $\left(\mathrm{Ph}_{3} \mathrm{C}\right)\left[\mathrm{B}\left(\mathrm{C}_{6} \mathrm{~F}_{5}\right)_{4}\right]$ at a ratio $[\mathrm{Zr}]:[\mathrm{Al}]:\left[\left(\mathrm{Ph}_{3} \mathrm{C}\right)\right.$ $\left.\left[\mathrm{B}\left(\mathrm{C}_{6} \mathrm{~F}_{5}\right)_{4}\right]\right]$ ]:[1-hexene $]=4: 16: 1: 1000$ and a temperature $40{ }^{\circ} \mathrm{C}$ affords alkene oligomers in both $\mathrm{CH}_{2} \mathrm{Cl}_{2}$ and $\mathrm{CHCl}_{3}$ (entries 50-52, 54, 55). Selective formation of a dimer $(92 \%$, entry 49) occurs in $\mathrm{CH}_{2} \mathrm{Cl}_{2}$ at $20{ }^{\circ} \mathrm{C}$, with the reaction time being up to $180 \mathrm{~min}$.

Subsequently, the content of dimers decreases to $55 \%$, and the amount of tetramer 7 increases to $33 \%$ (entry 50). Using chloroform as a solvent raises the yield of 7 to $65-72 \%$ (entries 54, 55).

The activity of $\mathrm{Cp}_{2} \mathrm{TiCl}_{2}(\mathbf{1 a})$ and $\mathrm{Cp}_{2} \mathrm{HfCl}_{2}(\mathbf{1} \mathbf{c})$ in the studied systems was lower than that of $\mathrm{Cp}_{2} \mathrm{ZrCl}_{2}(\mathbf{1 b})$. Indeed, the conversion of 1-hexene in $\mathrm{CH}_{2} \mathrm{Cl}_{2}$ at $40{ }^{\circ} \mathrm{C}$ was $80 \%$ in $60 \mathrm{~min}$ of the reaction in the case of the Ti complex (Table 2, entries 1) and $84 \%$ in $120 \mathrm{~min}$ for the Hf complex (entries 5). The use of chloroform as a solvent increases substrate conversion to $93 \%$ for $\mathrm{Cp}_{2} \mathrm{TiCl}_{2}$ and decreases the conversion to $60 \%$ for $\mathrm{Cp}_{2} \mathrm{HfCl}_{2}$ (entries $3,8)$. Moreover, these catalysts are significantly inferior in chemo- and regioselectivity to zirconocene dichloride. Thus, in the presence of $\mathrm{Cp}_{2} \mathrm{TiCl}_{2}$, the yield of oligomeric products 6 and tetramer 7 , which represent a mixture of regioisomers, increases in total to $89 \%$. The use of $\mathrm{Cp}_{2} \mathrm{HfCl}_{2}$ in $\mathrm{CH}_{2} \mathrm{Cl}_{2}$ leads to increased the content of vinylidene oligomers up to $28-37 \%$. In chloroform, the yield of regioisomeric oligomers also increases in the first $60 \mathrm{~min}$ of the reaction (entry 8). Further, the appearance of products of toluene mono-, di-, and trialkylation with 1-hexene was found (entries 9,10). It should be noted that in the presence of $\mathrm{HAlBu}^{\mathrm{i}}{ }_{2}$, upon replacing MMAO-12 with boron-containing activators, the systems based on $\mathrm{Cp}_{2} \mathrm{TiCl}_{2}$ and $\mathrm{Cp}_{2} \mathrm{HfCl}_{2}$ completely lost their activity (Table 2, entries 11-14).

The effect of the ligand structure of zirconocenes on the activity of catalytic systems and the reaction route was also studied. For this purpose, we tested $\mathrm{Zr} \eta^{5}$-complexes $\left(\mathrm{C}_{5} \mathrm{Me}_{5}\right)_{2} \mathrm{ZrCl}_{2}$ (1d), $\mathrm{Ind}_{2} \mathrm{ZrCl}_{2}$ (1e), and rac- $\mathrm{H}_{4} \mathrm{C}_{2}$ (THInd) ${ }_{2} \mathrm{ZrCl}_{2}$ (1) (Scheme 2) as components of the systems $\mathrm{L}_{2} \mathrm{ZrCl}_{2}-\mathrm{HAlBu}^{\mathrm{i}}{ }_{2}$-MMAO-12 at molar ratio [Zr]:[Al]:[MMAO-12]:[1hexene] $=1: 3: 30: 400$ and temperature of $40{ }^{\circ} \mathrm{C}$. It turned out that $\left(\mathrm{C}_{5} \mathrm{Me}_{5}\right)_{2} \mathrm{ZrCl}_{2}$ does not lead to the formation of the target products either in $\mathrm{CH}_{2} \mathrm{Cl}_{2}$ or in $\mathrm{CHCl}_{3}$ (Table 3, entries $1,2)$. In this case, 1-hexene was consumed for toluene alkylation (toluene is present in the system as a solvent for MMAO-12). The complex $\mathrm{Ind}_{2} \mathrm{ZrCl}_{2}$ showed lower activity than $\mathrm{Cp}_{2} \mathrm{ZrCl}_{2}$ (Table 3, entries 3-7) and shifted the reaction route toward the oligomerization (up to $87 \%$ ) both in $\mathrm{CH}_{2} \mathrm{Cl}_{2}$ and $\mathrm{CHCl}_{3}$. Ansa-zirconocene rac- $\mathrm{H}_{4} \mathrm{C}_{2}$ (THInd) ${ }_{2} \mathrm{ZrCl}_{2}$ was inactive in $\mathrm{CHCl}_{3}$ (entry 9); however, it catalyzed alkene oligomerization in $\mathrm{CH}_{2} \mathrm{Cl}_{2}$ (1-hexene conversion of $>99 \%$, entry 8 ). Thus, the zirconocene ligand structure significantly affects the course of the reaction, and some tested complexes mainly provided the formation of oligomeric products. 
Table 2. Catalytic activity and chemoselectivity of systems $\mathrm{Cp}_{2} \mathrm{MCl}_{2}-\mathrm{HAlBu}{ }_{2}{ }_{2}$-activator $(\mathrm{M}=\mathrm{Ti}$, $\mathrm{Hf})$ in the reaction with 1-hexene.

\begin{tabular}{|c|c|c|c|c|c|c|c|c|c|c|c|c|c|c|}
\hline \multirow{3}{*}{ Entry } & \multicolumn{3}{|c|}{ Catalytic Systems } & \multirow{3}{*}{$\begin{array}{c}\text { [Zr]: [Al]: } \\
\text { [Activator]:[1- } \\
\text { Alkene] }\end{array}$} & \multirow{3}{*}{ Solvent } & \multirow{3}{*}{$\mathrm{T},{ }^{\circ} \mathrm{C}$} & \multirow{3}{*}{$\begin{array}{l}\text { Time, } \\
\text { min }\end{array}$} & \multirow{3}{*}{$\begin{array}{c}\text { Alkene } \\
\text { Conver- } \\
\text { sion, } \\
\%\end{array}$} & \multicolumn{6}{|c|}{ Product Composition, $\%^{d}$} \\
\hline & \multirow{2}{*}{$\underset{\text { Complex }}{\mathrm{Zr}}$} & \multirow[b]{2}{*}{ OAC } & \multirow[b]{2}{*}{ Activator } & & & & & & \multirow{2}{*}{4} & \multirow{2}{*}{5} & \multicolumn{3}{|c|}{6} & \multirow{2}{*}{7} \\
\hline & & & & & & & & & & & $n=1$ & $n=2$ & $n=3$ & \\
\hline 1 & \multirow{4}{*}{$\underset{\mathrm{a}}{\mathrm{Cp}_{2} \mathrm{TiCl}_{2}}$} & \multirow{4}{*}{$\mathrm{HAlBu}_{2}{ }_{2}$} & \multirow{4}{*}{ MMAO-12 } & \multirow{4}{*}{$1: 3: 30: 400$} & \multirow{4}{*}{$\begin{array}{l}\mathrm{CH}_{2} \mathrm{Cl}_{2} \\
\mathrm{CHCl}_{3}\end{array}$} & \multirow{4}{*}{40} & 60 & 80 & & 20 & 34 & 4 & & $\overline{15}$ \\
\hline 2 & & & & & & & 180 & 91 & & 17 & 44 & 5 & & 20 \\
\hline 3 & & & & & & & 60 & 93 & & 16 & 36 & 6 & 5 & 28 \\
\hline 4 & & & & & & & 960 & $>99$ & 5 & 4 & 41 & 11 & 7 & 30 \\
\hline 5 & \multirow{7}{*}{$\mathrm{Cp}_{2} \mathrm{HfCl}_{2}$} & \multirow{7}{*}{$\mathrm{HAlBu}_{2}{ }_{2}$} & \multirow{3}{*}{ MMAO-12 } & \multirow{3}{*}{ 1:3:30:400 } & \multirow{3}{*}{$\mathrm{CH}_{2} \mathrm{Cl}_{2}$} & \multirow{3}{*}{40} & 120 & 84 & 2 & 53 & 20 & 6 & 2 & \\
\hline 6 & & & & & & & 180 & 94 & 2 & 54 & 21 & 8 & 2 & \\
\hline 7 & & & & & & & 960 & 96 & - & 59 & 22 & 8 & 3 & 4 \\
\hline 8 & & & \multirow{4}{*}{ MMAO-12 } & \multirow{4}{*}{ 1:3:30:400 } & \multirow{4}{*}{$\mathrm{CHCl}_{3}$} & \multirow{4}{*}{40} & 60 & 60 & - & 42 & 15 & 3 & & 1 \\
\hline & & & & & & & & & - & & & & & \\
\hline 9 & & & & & & & 120 & $74^{\mathrm{b}}$ & - & 30 & 16 & 4 & & 5 \\
\hline 10 & & & & & & & 960 & $>99^{c}$ & 6 & 17 & 17 & 15 & & 9 \\
\hline 11 & & & & \multirow{4}{*}{$4: 16: 1: 400$} & $\mathrm{CH}_{2} \mathrm{Cl}_{2}$ & & 960 & 0 & & & & & & \\
\hline 12 & $\mathrm{Cp}_{2} \mathrm{IiCl}_{2}$ & $\mathrm{HAlBu}_{2}{ }_{2}$ & $\left(\mathrm{Ph}_{3} \mathrm{C}\right)\left[\mathrm{B}\left(\mathrm{C}_{6} \mathrm{~F}_{5}\right)_{4}\right]$ & & $\mathrm{CHCl}_{3}$ & 40 & 960 & 0 & & & & & & \\
\hline 13 & \multirow{2}{*}{$\mathrm{Cp}_{2} \mathrm{HfCl}_{2}$} & $\mathrm{HAlBu}^{\mathrm{i}}$ & $\left(\mathrm{Ph}_{3} \mathrm{C}\right)\left[\mathrm{B}\left(\mathrm{C}_{6} \mathrm{~F}_{5}\right)_{4}\right]$ & & $\mathrm{CH}_{2} \mathrm{Cl}_{2}$ & 40 & 960 & 0 & & & & & & \\
\hline 14 & & & & & $\mathrm{CHCl}_{3}$ & 40 & 960 & 0 & & & & & & \\
\hline
\end{tabular}

${ }^{a}$ regioselectivity is significantly reduced due to double bond migration; ${ }^{\mathrm{b}}$ byproducts of toluene mono- $(13 \%)$, di- $(4 \%)$ and tri- $(2 \%)$ alkylation with 1-hexene are formed; ${ }^{c}$ byproducts of toluene mono- $(22 \%)$, di- $(7 \%)$, and tri- $(4 \%)$ alkylation with 1 -hexene are formed;

${ }^{d}$ wt \% in the reaction mixture, determined by GC-MS of deuterolysis or hydrolysis products (the details of the GC-MS analysis is shown in Supporting Information).

Table 3. Catalytic activity and chemoselectivity of systems $\mathrm{L}_{2} \mathrm{ZrCl}_{2}-\mathrm{HAlBu}_{2}{ }_{2}$-activator in the reaction with 1-hexene.

\begin{tabular}{|c|c|c|c|c|c|c|c|c|c|c|c|c|c|}
\hline \multirow[b]{2}{*}{ Entry } & \multicolumn{3}{|c|}{ Catalytic Systems } & \multirow{2}{*}{$\begin{array}{l}\text { [Zr]: [Al]: } \\
\text { [activator]:[1- } \\
\text { alkene] }\end{array}$} & \multirow[b]{2}{*}{ Solvent } & \multirow[b]{2}{*}{$\mathbf{T},{ }^{\circ} \mathrm{C}$} & \multirow[b]{2}{*}{$\begin{array}{l}\text { Time, } \\
\text { min }\end{array}$} & \multirow{2}{*}{$\begin{array}{c}\text { Alkene } \\
\text { Conver- } \\
\text { sion, } \\
\% \\
\end{array}$} & \multicolumn{5}{|c|}{ Product Composition, $\%$ e } \\
\hline & Zr Complex & OAC & Activator & & & & & & 4 & 5 & $n=1$ & $\begin{array}{c}6 \\
n=2\end{array}$ & $n=3$ \\
\hline $\begin{array}{l}1 \\
2 \\
\end{array}$ & $\left(\mathrm{C}_{5} \mathrm{Me}_{5}\right)_{2} \mathrm{ZrCl}_{2}$ & $\mathrm{HAlBu}_{2}{ }_{2}$ & MMAO-12 & 1:3:30:400 & $\begin{array}{l}\mathrm{CHCl}_{3} \\
\mathrm{CH}_{2} \mathrm{Cl}_{2}\end{array}$ & 40 & $\begin{array}{l}30 \\
30\end{array}$ & $>99^{a}$ & & & & & \\
\hline $\begin{array}{l}3 \\
4 \\
5 \\
6 \\
7\end{array}$ & $\mathrm{Ind}_{2} \mathrm{ZrCl}_{2}$ & $\mathrm{HAlBu}_{2}{ }_{2}$ & MMAO-12 & 1:3:30:400 & $\begin{array}{l}\mathrm{CH}_{2} \mathrm{Cl}_{2} \\
\mathrm{CHCl}_{3}\end{array}$ & $\begin{array}{l}40 \\
40\end{array}$ & $\begin{array}{c}30 \\
180 \\
960 \\
180 \\
960\end{array}$ & $\begin{array}{c}19 \\
48 \\
85^{\mathrm{b}} \\
>99 \\
>99^{\mathrm{c}}\end{array}$ & & $\begin{array}{l}11 \\
20 \\
9 \\
13 \\
16\end{array}$ & $\begin{array}{c}5 \\
19 \\
18 \\
51 \\
21\end{array}$ & $\begin{array}{c}2 \\
6 \\
18 \\
24 \\
19\end{array}$ & $\begin{array}{c}1 \\
3 \\
16 \\
12 \\
18\end{array}$ \\
\hline $\begin{array}{l}8 \\
9\end{array}$ & $\begin{array}{c}\text { rac- } \\
\mathrm{H}_{4} \mathrm{C}_{2}[\text { THInd }]_{2} \mathrm{ZrCl}_{2}\end{array}$ & $\mathrm{HAlBu}^{\mathrm{i}}{ }_{2}$ & MMAO-12 & 1:3:30:400 & $\begin{array}{l}\mathrm{CHCl}_{3} \\
\mathrm{CH}_{2} \mathrm{Cl}_{2}\end{array}$ & 40 & $\begin{array}{c}30 \\
960\end{array}$ & $\begin{array}{c}>99^{\mathrm{d}} \\
0^{2}\end{array}$ & & 39 & 38 & 16 & 4 \\
\hline
\end{tabular}

\subsection{NMR Study of Intermediate Structure in MMAO-12-Activated Systems $C p_{2} \mathrm{Zr} Y_{2}(Y=H$,} Cl)-OAC in Chlorinated Solvents

The effect of chlorinated solvents $\left(\mathrm{CD}_{2} \mathrm{Cl}_{2}\right.$ and $\left.\mathrm{CDCl}_{3}\right)$ on the structure of the intermediates responsible for the alkene dimerization in the catalytic systems $\left[\mathrm{Cp}_{2} \mathrm{ZrH}_{2}\right]_{2}-$ MMAO-12 was studied by NMR. The addition of MMAO-12 to a solution of $\left[\mathrm{Cp}_{2} \mathrm{ZrH}_{2}\right]_{2}$ in $\mathrm{CD}_{2} \mathrm{Cl}_{2}$ gives rise to a triplet at $-5.95 \mathrm{ppm}(\mathrm{J}=17.0 \mathrm{~Hz})$ in the ${ }^{1} \mathrm{H}$ NMR spectra (Figure $1 \mathrm{c}$, Figures S21-S23). In the COSY HH spectrum, the triplet correlates with the signal at $-0.47 \mathrm{ppm}$, which is superimposed with the region of resonance lines of methyl group protons of MMAO-12 ( $-0.82-0.32 \mathrm{ppm})$. The spectra also exhibited signals for the Cp rings at $6.16 \mathrm{ppm}$ (108.4 ppm in ${ }^{13} \mathrm{C}$ NMR spectra), $6.39 \mathrm{ppm}$ (112.8 ppm in ${ }^{13} \mathrm{C}$ NMR spectra), and $6.61 \mathrm{ppm}$ (116.2 $\mathrm{ppm}$ in ${ }^{13} \mathrm{C}$ NMR spectra). The NOESY spectra showed the cross-peaks of the Cp-ring signal at $6.16 \mathrm{ppm}$ with the upfield signals at $-5.95 \mathrm{ppm}$ and $-0.47 \mathrm{ppm}$. Relying on these results and the data from previous studies $[19,20]$, these signals were assigned to the biszirconium trihydride complex 9. The signals at $6.61 \mathrm{ppm}$ and $6.39 \mathrm{ppm}$ correspond to the $\mathrm{Cp}$ rings of $\mathrm{Cp}_{2} \mathrm{ZrCl}_{2}$ and $\mathrm{Cp}_{2} \mathrm{ZrMeCl}$ (11), respectively [27]. 


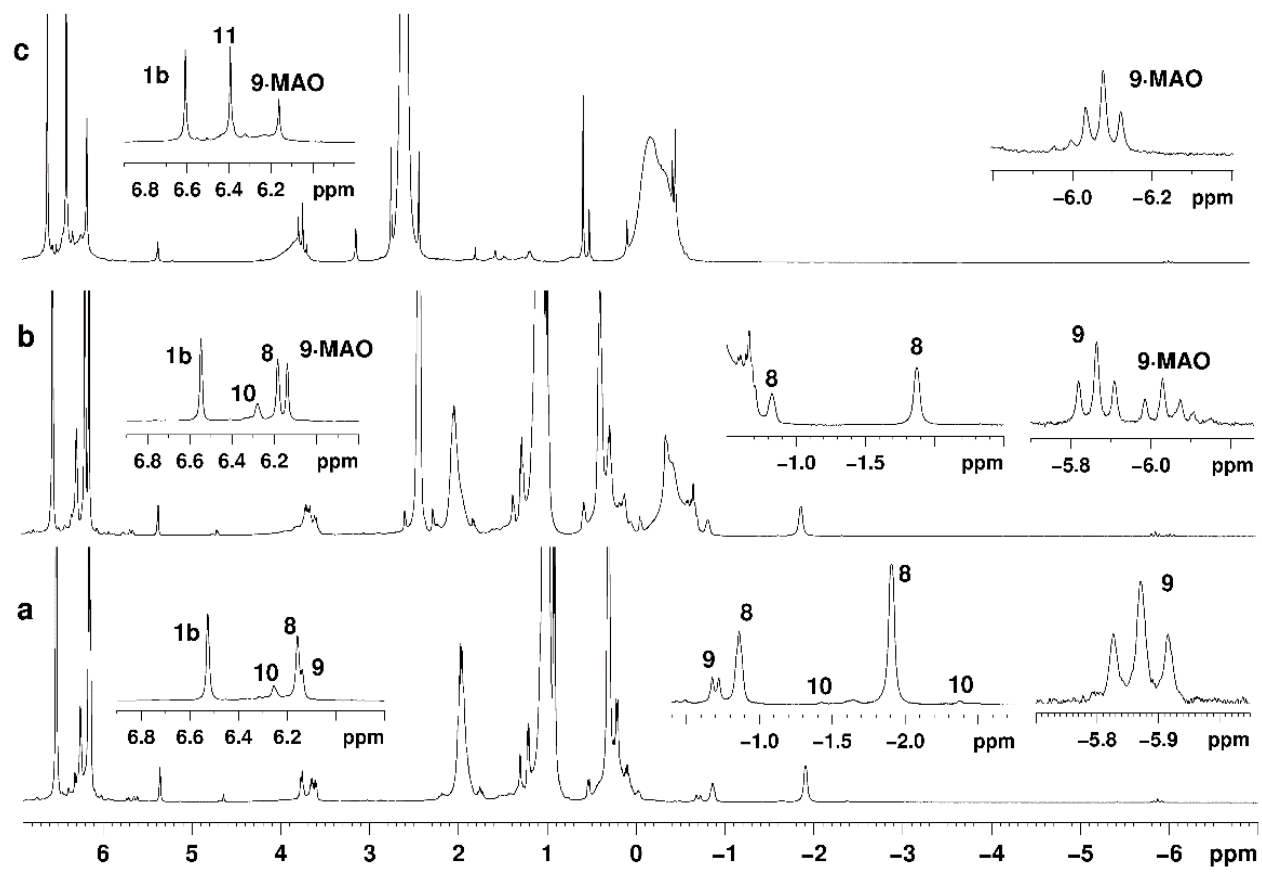

Figure 1. ${ }^{1} \mathrm{H}$ NMR spectrum of the system $\left[\mathrm{Cp}_{2} \mathrm{ZrH}_{2}\right]_{2}-\mathrm{ClAlBu}^{\mathrm{i}}{ }_{2}-\mathrm{MMAO}-12$ in $\mathrm{CD}_{2} \mathrm{Cl}_{2}(\mathrm{~T}=298 \mathrm{~K})$ : (a) $\left[\mathrm{Cp}_{2} \mathrm{ZrH}_{2}\right]:\left[\mathrm{ClAlBu}^{\mathrm{i}}{ }_{2}\right]:[\mathrm{MMAO}-12]=1: 2: 0$; (b) $\left[\mathrm{Cp}_{2} \mathrm{ZrH}_{2}\right]:\left[\mathrm{ClAlBu}{ }_{2}^{\mathrm{i}}\right]:[\mathrm{MMAO}-12]=1: 2: 5$; (c) $\left[\mathrm{Cp}_{2} \mathrm{ZrH}_{2}\right]:\left[\mathrm{ClAlBu}_{2}^{\mathrm{i}}\right][\mathrm{MMAO}-12]=1: 0: 7$.

As shown in Scheme 3, the system [ $\left.\mathrm{Cp}_{2} \mathrm{ZrH}_{2}\right]_{2}-\mathrm{MMAO}-12$ in $\mathrm{CD}_{2} \mathrm{Cl}_{2}$ produces complex 9 via in situ formation of $\mathrm{Cp}_{2} \mathrm{ZrHCl}$ and $\mathrm{Cp}_{2} \mathrm{ZrCl}_{2}$ by the reaction of zirconocene dihydride with a chlorine-containing solvent [28]. Residual AlMe 3 present in the MMAO12 solution reacts with $\mathrm{Cp}_{2} \mathrm{ZrCl}_{2}$ to give methyl chloride complex 11 and $\mathrm{ClAlMe}_{2}$. The reaction of $\mathrm{Cp}_{2} \mathrm{ZrHCl}$ with the starting $\mathrm{Cp}_{2} \mathrm{ZrH}_{2}$ and $\mathrm{ClAlMe}$ makes it possible to selectively obtain complex 9 and then high-molecular-weight associates with MMAO-12 (9.MAO), which are active in the alkene dimerization $[19,20]$.
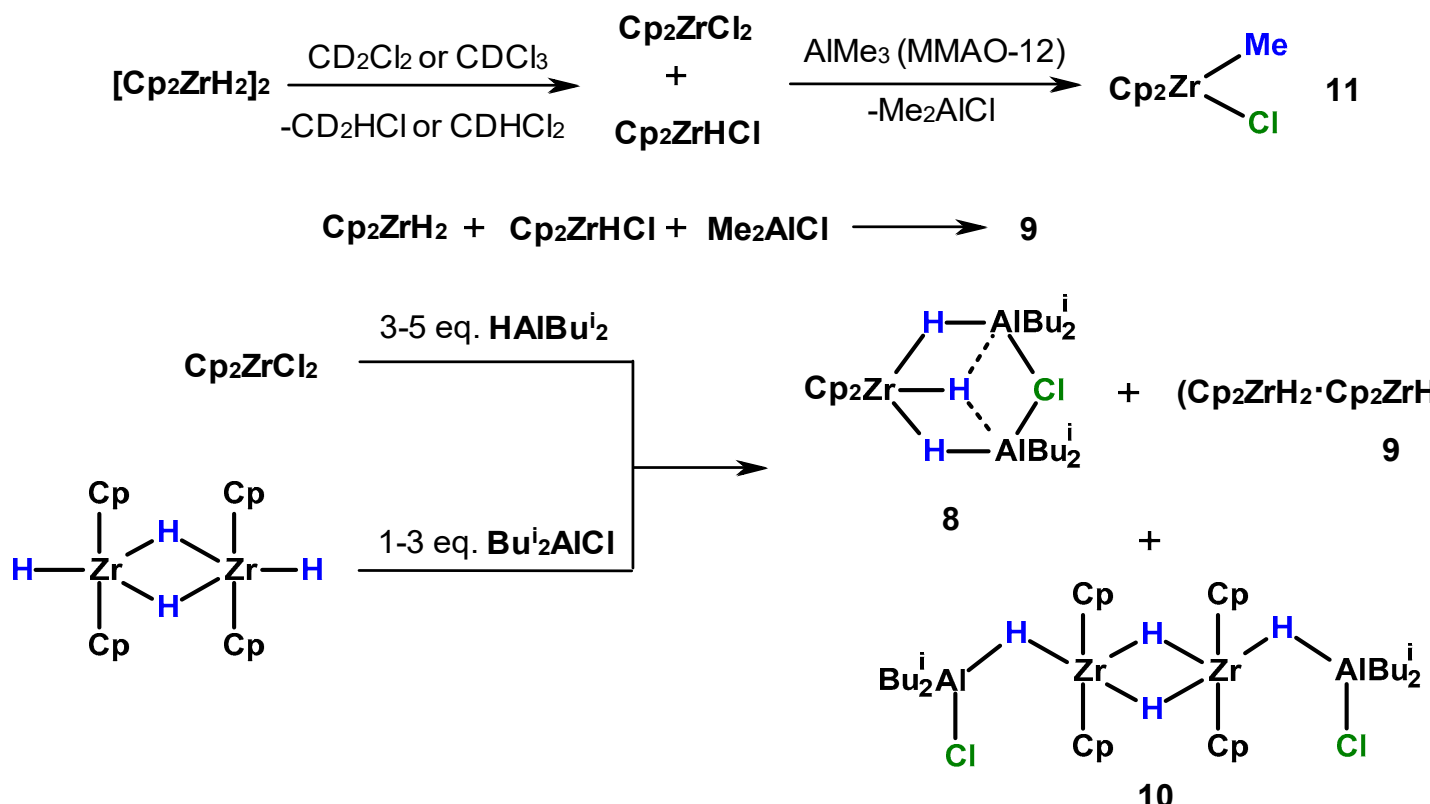

Scheme 3. The reaction of $\mathrm{Cp}_{2} \mathrm{ZrCl}_{2}$ and $\left[\mathrm{Cp}_{2} \mathrm{ZrH}_{2}\right]_{2}$ with $\mathrm{OACs}$ and MMAO-12. 
The ${ }^{1} \mathrm{H}$ and ${ }^{13} \mathrm{C}$ NMR spectra of the system $\left[\mathrm{Cp}_{2} \mathrm{ZrH}_{2}\right]_{2}-\mathrm{ClAlBu}_{2}{ }_{2}$ (Figure 1a, Figures S14 and S15) in $\mathrm{CD}_{2} \mathrm{Cl}_{2}$ exhibited signals of previously described intermediates [19,23,28,29]: complex 8 (broadened signals of hydride atoms at $\delta_{\mathrm{H}}-0.86$ and $-1.91 \mathrm{ppm}$ ), dimeric complex 10 (broadened signals of hydride atoms at $\delta_{\mathrm{H}}-1.42$ and $-2.38 \mathrm{ppm}$ ), and biszirconium trihydride complex 9 (doublet signal at $\delta_{\mathrm{H}}-0.70 \mathrm{ppm}\left({ }^{2} \mathrm{~J}=17.0 \mathrm{~Hz}\right.$ ) and triplet at $-5.87 \mathrm{ppm}$ ). The addition of MMAO- 12 to the equilibrium mixture of the complexes leads to the vanishing of signals of complex 10 from the ${ }^{1} \mathrm{H}$ NMR spectrum and the appearance of an additional triplet at $-6.01 \mathrm{ppm}$ attributable to the adduct 9.MAO (Figure 1b, Figures S16-S18).

A similar picture is observed in the ${ }^{1} \mathrm{H}$ and ${ }^{13} \mathrm{C}$ NMR spectra of $\mathrm{Cp}_{2} \mathrm{ZrCl}_{2}-\mathrm{HAlBu}_{2}{ }_{2}$ in $\mathrm{CD}_{2} \mathrm{Cl}_{2}$ (Figures $\mathrm{S} 5$ and S6). When MMAO-12 is added to the system, the signals of the dimeric complex 10 also disappear, the intensity of the signals of the trihydride 8 decreases, and additional triplets of 9.MAO appear in the upfield region at $-6.21 \div-5.92 \mathrm{ppm}$ (Figures S7 and S8).

The reaction of $\left[\mathrm{Cp}_{2} \mathrm{ZrH}_{2}\right]_{2}$ with MMAO-12 in either $\mathrm{CDCl}_{3}$ or $\mathrm{CD}_{2} \mathrm{Cl}_{2}$ gives complexes $\mathrm{Cp}_{2} \mathrm{ZrCl}_{2}\left(\delta_{\mathrm{Cp}} 6.76 \mathrm{ppm}\right)$ and $\mathrm{Cp}_{2} \mathrm{ZrMeCl}\left(\delta_{\mathrm{Cp}} 6.58 \mathrm{ppm}\right)$ (Figure 2c, Figures $\mathrm{S} 19$ and S20). Moreover, the ${ }^{1} \mathrm{H}$ NMR spectrum showed a significant broadening of the signals of the hydride atom at $-6.12 \mathrm{ppm}$ and $\mathrm{Cp}$ rings of the heavy adduct $9 \cdot \mathrm{MAO}$, which disappeared from the spectra due to the precipitation of the heavy fraction to the bottom of the NMR tube.

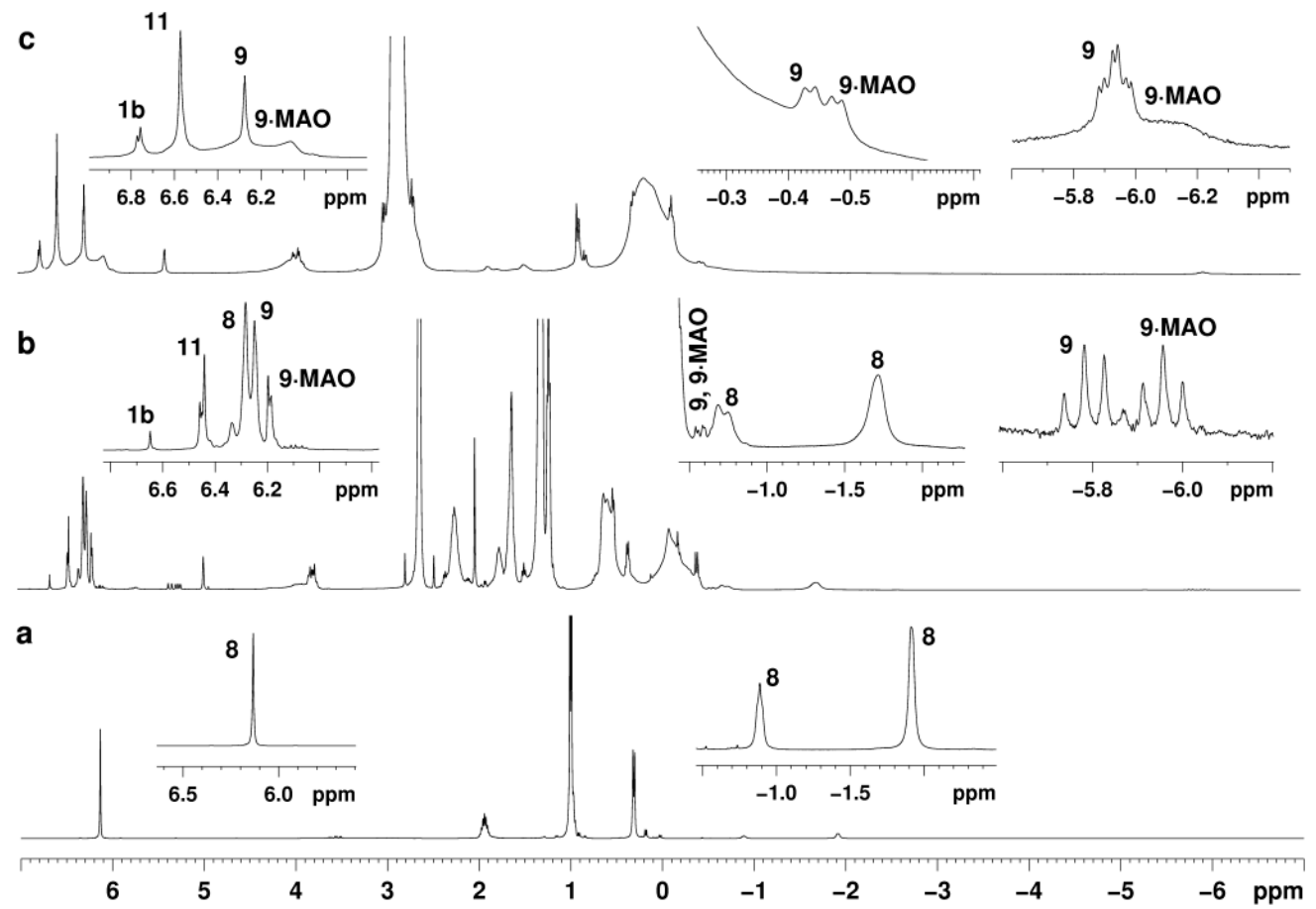

Figure 2. ${ }^{1} \mathrm{H}$ NMR spectrum of systems $\mathrm{Cp}_{2} \mathrm{ZrCl}_{2}-\mathrm{HAlBu}^{\mathrm{i}}{ }_{2}-\mathrm{MMAO}-12$ and $\left[\mathrm{Cp}_{2} \mathrm{ZrH}_{2}\right]_{2}-\mathrm{MMAO}-12$ in $\mathrm{CDCl}_{3}(\mathrm{~T}=298 \mathrm{~K}):(\mathbf{a})\left[\mathrm{Cp}_{2} \mathrm{ZrCl}_{2}\right]:\left[\mathrm{HAlBu}_{2}{ }_{2}\right]:[\mathrm{MMAO}-12]=1: 4: 0 ;(\mathbf{b})\left[\mathrm{Cp}_{2} \mathrm{ZrCl}_{2}\right]:\left[\mathrm{HAlBu}_{2}{ }_{2}\right]:[\mathrm{MMAO}-$ 12]:[1-hexene] = 1:2:11:0.1; (c) [C $\left.\mathrm{C}_{2} \mathrm{ZrH}_{2}\right]:[\mathrm{MMAO}-12]=1: 12$.

In the reaction of $\mathrm{Cp}_{2} \mathrm{ZrCl}_{2}$ with $\mathrm{HAlBu}_{2}{ }_{2}$ (1:4) in $\mathrm{CDCl}_{3}$, only the $\mathrm{Zr}$,Al-trihydride complex 8 was identified (Figure 2a, Figures S1 and S2). The signals of complexes 9 and 9.MAO appeared in the ${ }^{1} \mathrm{H}$ NMR spectra after the addition of MMAO-12 and 1-hexene to the system (Figure 2b, Figures S3 and S4). The formation of complexes 8-10 was observed in the reaction of zirconocene dihydride with $\mathrm{ClAlBu}_{2}{ }_{2}$ taken in a 1:2 ratio in $\mathrm{CDCl}_{3}$ (Figure S9). The addition of MMAO- 12 to this system results in the disappearance of signals of complex 10, broadening of complex 8 signals, and the appearance of an additional broadened multiplet at $-6.03 \mathrm{ppm}$, corresponding to the heavy adduct 9.MAO (Figure S11). NMR monitoring of the system's reaction with 1-hexene showed the consumption of 9.MAO adduct and the accumulation of the vinylidene dimer (Figures S24 and S25). 
Thus, biszirconium complex 9 is readily formed in the systems $\mathrm{Cp}_{2} \mathrm{ZrCl}_{2}-\mathrm{HAlBu}^{\mathrm{i}}{ }_{2}$, $\left[\mathrm{Cp}_{2} \mathrm{ZrH}_{2}\right]_{2}-\mathrm{MMAO}-12$, and $\left[\mathrm{Cp}_{2} \mathrm{ZrH}_{2}\right]_{2}-\mathrm{ClAlBu}^{\mathrm{i}}{ }_{2}$ both in $\mathrm{CD}_{2} \mathrm{Cl}_{2}$ and in $\mathrm{CDCl}_{3}$. This intermediate reacts with methylaluminoxane to give a heavy adduct, which selectively provides vinylidene dimers of 1-hexene.

\subsection{DFT Study of the Structure of Biszirconium Complex 9}

To refine the structure of complex $\mathbf{9}$, probable structures of cyclic isomers $\mathbf{9 a - 9 d}$ were optimized using the $\mathrm{PBE} / 3 \zeta$ quantum chemical method [30-32]. Their structure is in line with the obtained NMR spectral data on the ratio of the signal intensities of the constituent moieties and the symmetry of the complex (Scheme 4). As follows from Scheme 4 , the structures of the complexes significantly differ from one another. For example, in complex $9 \mathbf{c}$, all three hydrides are located between the zirconium atoms and form a trihydride bridge, while in molecule $\mathbf{9 a}$, there is only one bridging $\mathrm{H}$ atom. If the optimized structures of the two most energetically favorable hydride complexes $9 \mathbf{a}$ and $\mathbf{9 c}$ (Figure 3) are considered in detail, the length of the $\mathrm{Zr}-\mathrm{H}$ bond varies, which may cause differences in the reactivity of the studied complexes. Thus, the lengths of both $\mathrm{Zr}-\mathrm{H}$ bonds in the $\mathrm{Zr}-\mathrm{H}-\mathrm{Zr}$ moiety of complex $9 \mathrm{a}$ is $2.09 \AA$, while the lengths of two terminal $\mathrm{Zr}-\mathrm{H}$ bonds are $d_{\mathrm{Zr} 1-\mathrm{H}}=d_{\mathrm{Zr2}-\mathrm{H}}=1.83 \AA$. It is comparable with the $\mathrm{Zr}-\mathrm{H}$ bond length in $\mathrm{Cp}_{2} \mathrm{ZrHCl}$ calculated by the same method $\left(d_{\mathrm{Zr}-\mathrm{H}}=1.84 \AA\right)$.



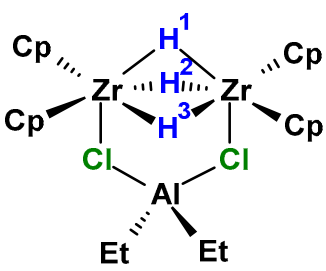

$9 c$





9d

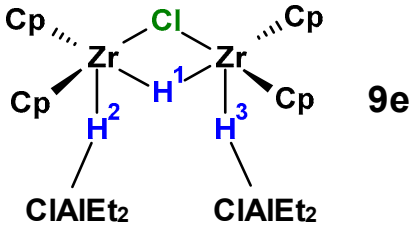

Scheme 4. Theoretically calculated structures of isomers of complex 9.
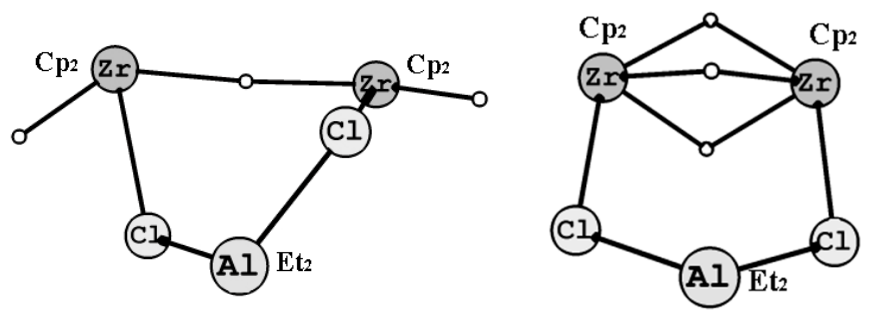

Figure 3. Optimized structures of isomers $9 \mathbf{a}$ and $9 c$.

In isomer $9 c$, all three hydrogen atoms are inside the biszirconium cage. Meanwhile, the lengths of bridging $\mathrm{Zr}-\mathrm{H}$ bonds are also increased compared to those in $\mathrm{Cp}_{2} \mathrm{ZrHCl}$, but are not equivalent to each other: $d_{\mathrm{Zr} 1-\mathrm{H} 1}=d_{\mathrm{Zr2}-\mathrm{H} 1}=2.01 \AA, d_{\mathrm{Zr} 1-\mathrm{H} 2}=d_{\mathrm{Zr} 2-\mathrm{H} 3}=1.97 \AA$, $d_{\mathrm{Zr} 1-\mathrm{H} 3}=d_{\mathrm{Zr2}-\mathrm{H} 2}=1.99 \AA$. Thus, one hydrogen atom is equidistant from both zirconium atoms, while the other two $\mathrm{H}$ atoms, forming an "inner" bridge, are characterized by 
some displacement towards one of the zirconium atoms. It is quite obvious that structural differences also determine energy differences (Table 4, Table S1).

Table 4. Relative thermodynamic parameters of isomeric complexes 9.

\begin{tabular}{cccccc}
\hline Complex & $\boldsymbol{\Delta E}$, Hartree & $\begin{array}{c}\Delta \mathrm{E}_{\mathbf{Z P V E}} \\
\text { Hartree }\end{array}$ & $\begin{array}{c}\boldsymbol{\Delta H}, \\
\mathbf{k c a l} / \mathbf{m o l}\end{array}$ & $\begin{array}{c}\Delta \mathrm{G}, \\
\mathbf{k c a l} / \mathbf{m o l}\end{array}$ & $\begin{array}{c}\mathbf{T} \boldsymbol{\Delta S}, \\
\mathbf{c a l} / \mathbf{m o l}\end{array}$ \\
\hline 9a & 0.000000 & 0.000000 & 0.0 & 0.0 & 2475.2 \\
9b & 0.013103 & 0.012948 & 8.2 & 9.6 & 1139.2 \\
9c & 0.003022 & 0.003398 & 2.4 & 3.3 & 1517.2 \\
9d & 0.022146 & 0.023111 & 14.4 & 16.9 & 0.0 \\
\hline
\end{tabular}

The most thermodynamically stable complex is $\mathbf{9 a}$, in which the chlorine atoms are part of the $\mathrm{Zr}-\mathrm{Cl}-\mathrm{Al}$ moieties. Isomer $\mathbf{9 b}$ is higher in energy by $3.3 \mathrm{kcal} / \mathrm{mol}$. The presence of bulky $\mathrm{Cl}$ atoms in the inner bridge of the biszirconium cage of structure $\mathbf{9 d}$ makes this complex least thermodynamically stable relative to other compounds.

To identify the structure of the complex observed by NMR spectroscopy, we compared theoretical and experimental NMR chemical shifts of hydride atoms in each of them (Table 5). It was found that in complex 9a, the hydrogen atom of the $\mathrm{Zr}-\mathrm{H}-\mathrm{Zr}$ moiety is significantly shielded $\left(\delta \mathrm{H}^{1}=-4.2 \mathrm{ppm}\right)$, while two other hydride atoms experience a de-shielding effect $\left(\delta \mathrm{H}^{2}=\delta \mathrm{H}^{3}=2.9 \mathrm{ppm}\right)$. Thus, the difference in chemical shifts between the considered hydrogen atoms is $\Delta \delta=7.1 \mathrm{ppm}$, which is in good agreement with the experimental data. A similar trend is also observed for complex 9c, in which one of the hydride atoms of the inner $\mathrm{Zr}-\mathrm{H}-\mathrm{Zr}$ bridge should be in the upfield region of the ${ }^{1} \mathrm{H}$ NMR spectrum. As follows from Table 5, the calculated NMR data for complexes $\mathbf{9 b}$ and $\mathbf{9 d}$ are in poor agreement with the NMR spectral parameters observed. It should be noted for comparison that the calculated chemical shifts of the hydride atoms of the open structure 9e proposed earlier [23] also do not agree well with the NMR experiment. As a result of a comprehensive analysis of chemical shifts and relative Gibbs energy, the complex 9a was proposed as the most probable structure.

Table 5. Calculated and experimental chemical shifts of isomeric complexes $\mathbf{9 a}-\mathbf{d}$ (numbering according to Scheme 4).

\begin{tabular}{ccccc}
\hline Complex & $\boldsymbol{\delta}\left(\mathbf{H}^{\mathbf{1}}\right), \mathbf{p p m}$ & $\boldsymbol{\delta}\left(\mathbf{H}^{\mathbf{2}}\right), \mathbf{p p m}$ & $\boldsymbol{\delta}\left(\mathbf{H}^{\mathbf{3}}\right), \mathbf{p p m}$ & $\boldsymbol{\delta}(\mathbf{C p}), \mathbf{p p m}$ \\
\hline $9 \mathrm{a}$ & -4.2 & 2.9 & 2.9 & 5.9 \\
$9 \mathrm{~b}$ & -2.3 & 1.8 & 1.8 & 6.2 \\
$9 \mathrm{c}$ & -3.6 & 3.7 & 3.7 & 6.2 \\
$9 \mathrm{~d}$ & 0.7 & 0.8 & 0.8 & 6.0 \\
$9 \mathrm{e}$ & -1.6 & -0.4 & -0.4 & 6.1 \\
9 (experimental) & -5.9 & -0.7 & -0.7 & 6.1 \\
\hline
\end{tabular}

\section{Materials and Methods}

\subsection{General Procedures}

All operations for organometallic compounds were performed under argon according to the Schlenk technique. Zirconocene 1 was prepared from $\mathrm{ZrCl}_{4}$ (99.5\%, Merck, Darmstadt, Germany) using the standard procedure [33]. The synthesis of $\left[\mathrm{Cp}_{2} \mathrm{ZrH}_{2}\right]_{2}$ (2) from (1) was carried out as described previously [28,34]. The solvents $\left(\mathrm{CHCl}_{3}, \mathrm{CH}_{2} \mathrm{Cl}_{2}\right.$, $\mathrm{ClCH}_{2} \mathrm{CH}_{2} \mathrm{Cl}$ ) were distilled from $\mathrm{P}_{2} \mathrm{O}_{5}$ immediately before use. The solvent $o-\mathrm{Cl}_{2} \mathrm{C}_{6} \mathrm{H}_{4}$ (anhydrous, 99\%, Merck) was used without further purification. Commercially available $\mathrm{Cp}_{2} \mathrm{HfCl}_{2}$ (98\%, Strem, Newburyport, MA, USA), $\mathrm{Cp}_{2} \mathrm{TiCl}_{2}\left(99 \%\right.$, Strem), $\left(\mathrm{C}_{5} \mathrm{Me}_{5}\right)_{2} \mathrm{ZrCl}_{2}$ (97\%, Acros), rac- $\mathrm{C}_{2} \mathrm{H}_{4}$ (THInd) ${ }_{2} \mathrm{ZrCl}_{2}$ (97\%, Merck), HAlBu${ }_{2}^{\mathrm{i}}$ (99\%, Merck), ClAlBu ${ }_{2}{ }_{2}$ (97\%, Strem), MMAO-12 (7\% wt Al in toluene, Merck), $\left(\mathrm{Ph}_{3} \mathrm{C}\right)\left[\mathrm{B}\left(\mathrm{C}_{6} \mathrm{~F}_{5}\right)_{4}\right](97 \%, \mathrm{Abcr}, \mathrm{Karl}-$ sruhe, Germany), $\mathrm{B}\left(\mathrm{C}_{6} \mathrm{~F}_{5}\right)_{3}(95 \%$, Merck), and 1-hexene (97\%, Fisher Scientific, Pittsburgh, Pennsylvania, USA) were used for the reactions. 
CAUTION: pyrophoric nature of aluminum alkyl and hydride compounds requires special safety precautions in their handling.

${ }^{1} \mathrm{H}$ and ${ }^{13} \mathrm{C}$ NMR spectra were recorded on a Bruker AVANCE-400 spectrometer (400.13 MHz $\left.\left({ }^{1} \mathrm{H}\right), 100.62 \mathrm{MHz}\left({ }^{13} \mathrm{C}\right)\right)$ (Bruker, Rheinstetten, Germany). As the solvents and the internal standards, $\mathrm{CD}_{2} \mathrm{Cl}_{2}$ and $\mathrm{CDCl}_{3}$ were employed. $1 \mathrm{D}$ and 2D NMR spectra (COSY $\mathrm{HH}, \mathrm{HSQC}, \mathrm{HMBC}, \mathrm{NOESY}$ ) were recorded using standard Bruker pulse sequences.

The products were analyzed using a GC-MS-QP2010 Ultra gas chromatograph-mass spectrometer (Shimadzu, Tokyo, Japan) equipped with the GC-2010 Plus chromatograph (Shimadzu, Tokyo, Japan), TD-20 thermal desorber (Shimadzu, Tokyo, Japan), and an ultrafast quadrupole mass-selective detector (Shimadzu, Tokyo, Japan). Details on the GC-MS analysis of dimers and oligomers are given in the SI.

\subsection{Reaction of $\left[\mathrm{Cp}_{2} \mathrm{ZrH}_{2}\right]_{2}$ with $\mathrm{ClAlBu}{ }_{2}{ }_{2}$, Activators (MMAO-12, $\left(\mathrm{Ph}_{3} \mathrm{C}\right)\left[B\left(\mathrm{C}_{6} \mathrm{~F}_{5}\right)_{4}\right]$ or $\left.B\left(C_{6} F_{5}\right)_{3}\right)$ and 1-Hexene}

A flask with a magnetic stirrer was filled under argon with $10 \mathrm{mg}(0.045 \mathrm{mmol})$ $\left[\mathrm{Cp}_{2} \mathrm{ZrH}_{2}\right]_{2}$ (all ratios are given relative to the monomer), $0.026 \mathrm{~mL}(0.135 \mathrm{mmol}) \mathrm{ClAlBu}_{2}{ }_{2}$, $0.58 \mathrm{~mL}$ (1.35 mmol) MMAO-12, $2.24 \mathrm{~mL}$ or 5,63 mL (17.9 or $45 \mathrm{mmol}$ ) 1-hexene, and $2 \mathrm{~mL}$ solvent $\left(\mathrm{CHCl}_{3}, \mathrm{CH}_{2} \mathrm{Cl}_{2}, o-\mathrm{Cl}_{2} \mathrm{C}_{6} \mathrm{H}_{4}, \mathrm{ClCH}_{2} \mathrm{CH}_{2} \mathrm{Cl}\right)$. For organoboron activators $\left(\mathrm{Ph}_{3} \mathrm{C}\right)\left[\mathrm{B}\left(\mathrm{C}_{6} \mathrm{~F}_{5}\right)_{4}\right]$ or $\mathrm{B}\left(\mathrm{C}_{6} \mathrm{~F}_{5}\right)_{3}$ the following amounts were used: $10 \mathrm{mg}(0.045 \mathrm{mmol})$ $\left[\mathrm{Cp}_{2} \mathrm{ZrH}_{2}\right]_{2}, 0.018-0.036 \mathrm{~mL}(0.10-0.18 \mathrm{mmol}) \mathrm{ClAlBu}_{2}^{\mathrm{i}}, 6 \mathrm{mg}(0.011 \mathrm{mmol}) \mathrm{B}\left(\mathrm{C}_{6} \mathrm{~F}_{5}\right)_{3}$ or $10 \mathrm{mg}(0.011 \mathrm{mmol})\left(\mathrm{Ph}_{3} \mathrm{C}\right)\left[\mathrm{B}\left(\mathrm{C}_{6} \mathrm{~F}_{5}\right)_{4}\right], 0.6 \mathrm{~mL}(4.5 \mathrm{mmol})$ 1-hexene, and $2 \mathrm{~mL}$ solvent $\left(\mathrm{CHCl}_{3}, \mathrm{CH}_{2} \mathrm{Cl}_{2}, o-\mathrm{Cl}_{2} \mathrm{C}_{6} \mathrm{H}_{4}, \mathrm{ClCH}_{2} \mathrm{CH}_{2} \mathrm{Cl}\right)$. The reaction was carried out with stirring at a temperature of $40^{\circ} \mathrm{C}$. After 5, 10, 15, 30, 60, 90, 120, 180, and $960 \mathrm{~min}$, samples $(0.1 \mathrm{~mL})$ were syringed into tubes filled with argon and decomposed with $10 \% \mathrm{HCl}$ at $0{ }^{\circ} \mathrm{C}$. The products were extracted with $\mathrm{CH}_{2} \mathrm{Cl}_{2}$, and the organic layer was dried over $\mathrm{Na}_{2} \mathrm{SO}_{4}$. The yield of dimers or oligomers was determined by GC/MS.

\subsection{Reaction of $\mathrm{L}_{2} \mathrm{MCl}_{2}(\mathbf{1} a-f)$ with $\mathrm{HAlB}{ }^{i}{ }_{2}, \mathrm{MMAO}-12,\left(\mathrm{Ph}_{3} \mathrm{C}\right)\left[B\left(\mathrm{C}_{6} \mathrm{~F}_{5}\right)_{4}\right]$ or $B\left(\mathrm{C}_{6} F_{5}\right)_{3}$ and 1-Hexene}

A flask with a magnetic stirrer was filled under argon with $0.034 \mathrm{mmol}(9-15 \mathrm{mg})$ $\mathrm{L}_{2} \mathrm{MCl}_{2}, 0.019 \mathrm{~mL}$ (0.108 mmol) HAlBu ${ }_{2}, 0.44 \mathrm{~mL}$ (1.02 mmol) MMAO-12, 1.7 or $4.2 \mathrm{~mL}$ (13.6 or $34 \mathrm{mmol}$ ) 1-hexene, and $2 \mathrm{~mL}$ solvents $\left(\mathrm{CHCl}_{3}, \mathrm{CH}_{2} \mathrm{Cl}_{2}, o-\mathrm{Cl}_{2} \mathrm{C}_{6} \mathrm{H}_{4}, \mathrm{ClCH}_{2} \mathrm{CH}_{2} \mathrm{Cl}\right.$ ). For organoboron activators $\left(\mathrm{Ph}_{3} \mathrm{C}\right)\left[\mathrm{B}\left(\mathrm{C}_{6} \mathrm{~F}_{5}\right)_{4}\right]$ or $\mathrm{B}\left(\mathrm{C}_{6} \mathrm{~F}_{5}\right)_{3}$ the following amounts were used: $0.034 \mathrm{mmol}(9-15 \mathrm{mg}) \mathrm{L}_{2} \mathrm{MCl}_{2}, 0.018-0.036 \mathrm{~mL}(0.10-0.18 \mathrm{mmol}) \mathrm{HAlBu}^{\mathrm{i}}{ }_{2}, 5 \mathrm{mg}$ $(0.0085 \mathrm{mmol}) \mathrm{B}\left(\mathrm{C}_{6} \mathrm{~F}_{5}\right)_{3}$ or $10-16 \mathrm{mg}(0.011-0.017 \mathrm{mmol})\left(\mathrm{Ph}_{3} \mathrm{C}\right)\left[\mathrm{B}\left(\mathrm{C}_{6} \mathrm{~F}_{5}\right)_{4}\right], 1$ or $1.7 \mathrm{~mL}(8.5$ or $13.6 \mathrm{mmol})$ 1-hexene, and $2 \mathrm{~mL}$ solvents $\left(\mathrm{CHCl}_{3}, \mathrm{CH}_{2} \mathrm{Cl}_{2}, \mathrm{o}-\mathrm{Cl}_{2} \mathrm{C}_{6} \mathrm{H}_{4}, \mathrm{ClCH}_{2} \mathrm{CH}_{2} \mathrm{Cl}\right)$. The reaction was carried out with stirring at a temperature of $40{ }^{\circ} \mathrm{C}$. After $15,20,30$, $60,90,120,180$, and $960 \mathrm{~min}$, samples $(0.1 \mathrm{~mL})$ were syringed into tubes filled with argon and decomposed with $10 \% \mathrm{HCl}$ or $\mathrm{DCl}$ at $0{ }^{\circ} \mathrm{C}$. The products were extracted with $\mathrm{CH}_{2} \mathrm{Cl}_{2}$, and the organic layer was dried over $\mathrm{Na}_{2} \mathrm{SO}$. The yields of the products were determined by GC/MS.

\subsection{NMR Study of the Reaction of $\left[\mathrm{Cp}_{2} \mathrm{ZrH}_{2}\right]_{2}$ with $\mathrm{ClAlR}_{2}$ and $M M A O-12$}

An NMR tube was charged with $0.045 \mathrm{mmol}(10 \mathrm{mg})\left[\mathrm{Cp}_{2} \mathrm{ZrH}_{2}\right]_{2}$ in an argon-filled glovebox. The tube was cooled to $0{ }^{\circ} \mathrm{C}$, and $0.045-0.2 \mathrm{mmol}(8-35.3 \mathrm{mg}) \mathrm{ClAlBu}{ }^{\mathrm{i}}{ }_{2}$ was added dropwise. Then $\mathrm{CDCl}_{3}$ or $\mathrm{CD}_{2} \mathrm{Cl}_{2}$ was added. The mixture was stirred, and the formation of complexes 8-10 was monitored by NMR at room temperature. Then $0.135-0.9 \mathrm{mmol}$ (60-300 mg) MMAO-12 was added, and the formation of intermediates was monitored by NMR at room temperature (Figures S9-S18).

In the case of the system $\left[\mathrm{Cp}_{2} \mathrm{ZrH}_{2}\right]_{2}-\mathrm{MMAO}-12$, the number of components was the same as described above (Figures S19-S23). The deuterated solvent was added to the NMR tube as the last component. 


\subsection{NMR Study of the Reaction of $\mathrm{Cp}_{2} \mathrm{ZrCl}_{2}$ with $\mathrm{HAlBu}_{2}{ }_{2}$ and $\mathrm{MMAO}-12$}

An NMR tube was charged with $0.034 \mathrm{mmol}(10 \mathrm{mg}) \mathrm{Cp}_{2} \mathrm{ZrCl}_{2}$ in an argon-filled glovebox. The tube was cooled to $0{ }^{\circ} \mathrm{C}$, and $0.068-0.136 \mathrm{mmol}(10-19.3 \mathrm{mg}) \mathrm{HAlBu}^{\mathrm{i}}{ }_{2}$ was added dropwise. Then $\mathrm{CDCl}_{3}$ or $\mathrm{CD}_{2} \mathrm{Cl}_{2}$ was added. The mixture was stirred, and the formation of complexes $\mathbf{8 - 1 0}$ was monitored by NMR at room temperature. Then $0.135-0.9 \mathrm{mmol}$ (60-300 $\mathrm{mg}$ ) MMAO-12 was added, and the formation of intermediates was monitored by NMR at room temperature (Figures S1-S8).

\subsection{Computational Details}

DFT calculations were carried out in Priroda-06 program [32,35]. Geometry optimization, vibrational frequency analysis, and calculation of absolute chemical shielding, entropy, and thermodynamic corrections to the total energy of the compounds were carried out using the Perdew-Burke-Ernzerhof (PBE) functional [30]. PBE functional was used in combination with a $3 \zeta$ basis set [31]. The electronic configurations of the molecular systems were described by the orbital basis sets of contracted Gaussian-type functions of size (5s1p)/[3s1p] for $\mathrm{H},(11 \mathrm{~s} 6 \mathrm{p} 2 \mathrm{~d}) /[6 \mathrm{~s} 3 \mathrm{p} 2 \mathrm{~d}]$ for C, $(15 \mathrm{~s} 11 \mathrm{p} 2 \mathrm{~d}) /[10 \mathrm{~s} 6 \mathrm{p} 2 \mathrm{~d}]$ for $\mathrm{Al}$ and $\mathrm{Cl}$, and (20s16p11d)/[14s11p7d] for $\mathrm{Zr}$, which were used in combination with the densityfitting basis sets of uncontracted Gaussian-type functions of size (5s2p) for H, (10s3p3d1f) for $\mathrm{C},(14 \mathrm{~s} 3 \mathrm{p} 3 \mathrm{~d} 1 \mathrm{f} 1 \mathrm{~g})$ for $\mathrm{Al}$ and $\mathrm{Cl}$, and (22s5p5d4f4g) for $\mathrm{Zr}$. No symmetry of internal coordinate constraints was applied during optimizations. Thermodynamic parameters were determined at 298.15. Normal-mode vibrational frequency analysis was performed to confirm minima structures. Computations of absolute chemical shielding, $\sigma$, were carried out in the GIAO approach [36,37]. Chemical shifts were calculated as $\delta=\sigma_{\text {TMS }}-\sigma$, where $\sigma_{\text {TMS }}$ was the calculated shielding constant of tetramethylsilane. For comparison, structural and energetic parameters of complexes 9a-e were calculated using Gaussian 09 [38] at the PBE0 level of theory [39] employing the def2-TZVP basis set [40,41] with and without Grimme's D3(0) empirical dispersion correction (GD3) [42] (Tables S2 and S3). Moreover, the method was successfully employed to calculate chemical shifts of Au hydrides [43]. Calculated chemical shifts obtained for $9 a$ by two methods was comparable (PBE0/def2TZVP: $\left.\delta \mathrm{H}^{1}=-3.5 \mathrm{ppm}, \delta \mathrm{H}^{2}=3.1 \mathrm{ppm}, \delta \mathrm{H}^{3}=3.1 \mathrm{ppm}\right)$. Therefore, the $\mathrm{PBE} / 3 \zeta$ method was used for the calculation of the chemical shifts of other complexes. As follows from Table S3 (Supporting Information), using the GD3 correction does not lead to significant changes in the energy of the studied complexes. Furthermore, we carried out the study on the solvent effect $\left(\mathrm{CH}_{2} \mathrm{Cl}_{2}\right.$ and $\left.\mathrm{CHCl}_{3}\right)$ using the conductor-like polarizable continuum model (CPCM) $[44,45]$. The data indicated minor energy changes (Supporting Information, Tables S4 and S5).

The program ChemCraft [46] was used to visualize obtained quantum chemical data. The energy at $0 \mathrm{~K}$, the ZPVE correction, the enthalpy, the Gibbs free energy in gas, the temperature multiplied by the entropy, and Cartesian coordinates for all optimized structures are given in the Supporting Information.

\section{Conclusions}

As a result of studying the catalytic transformations of 1-hexene under the action of $\mathrm{Ti}$ group metallocenes, organoaluminum compounds, and activators MMAO- $12, \mathrm{~B}\left(\mathrm{C}_{6} \mathrm{~F}_{5}\right)_{3}$ or $\left(\mathrm{Ph}_{3} \mathrm{C}\right)\left[\mathrm{B}\left(\mathrm{C}_{6} \mathrm{~F}_{5}\right)_{4}\right]$ in chlorinated solvents, it was found that systems based on $\mathrm{Zr}$ complexes [C $\left.\mathrm{Cp}_{2} \mathrm{ZrH}_{2}\right]_{2}-\mathrm{ClAlBu}{ }_{2}{ }_{2}-\mathrm{MMAO}-12, \mathrm{Cp}_{2} \mathrm{ZrCl}_{2}-\mathrm{HAlBu}_{2}{ }_{2}-\mathrm{MMAO}-12$ in $\mathrm{CH}_{2} \mathrm{Cl}_{2}$ selectively afford dimeric products in high yields. The use of $\mathrm{CHCl}_{3}$ as the solvent facilitates the formation of non-classical tetramers of 1-hexene, the products of dimer dimerization.

NMR studies showed that systems $\mathrm{Cp}_{2} \mathrm{ZrCl}_{2}-\mathrm{HAlBu}^{\mathrm{i}}{ }_{2}-\mathrm{MMAO}-12,\left[\mathrm{Cp}_{2} \mathrm{ZrH}_{2}\right]_{2}-\mathrm{MMAO}$ -12 , and $\left[\mathrm{Cp}_{2} \mathrm{ZrH}_{2}\right]_{2}-\mathrm{ClAlBu}{ }_{2}{ }_{2}-\mathrm{MMAO}-12$ provide the adduct of biszirconium complex $\left(\mathrm{Cp}_{2} \mathrm{ZrH}_{2} \cdot \mathrm{Cp}_{2} \mathrm{ZrHCl} \cdot \mathrm{ClAlR}_{2}\right)$ with an activator both in $\mathrm{CD}_{2} \mathrm{Cl}_{2}$ and $\mathrm{CDCl}_{3}$. The adduct reacts with 1-hexene and produces a vinylidene dimer.

The probable structure of the key biszirconium hydride complex was proposed based on a comparison of experimental and theoretical NMR data and estimation of the thermo- 
dynamical stability of the complexes. These studies are necessary to further understand the mechanism of key intermediate activation by methylaluminoxane or organoboron compounds for selective alkene dimerization.

Supplementary Materials: Supplementary Materials are available online. Figures S1-S27: NMR spectra of catalytic systems, Figures S28 and S29: Examples of GC-MS analysis of dimers and oligomers, Tables S1-S5: Calculated thermodynamic parameters of isomeric complexes $\mathbf{9 a - d}$.

Author Contributions: Conceptualization, L.V.P.; methodology, P.V.K. and T.V.T; validation, L.V.P., P.V.K. and T.V.T.; formal analysis, P.V.K. and T.V.T.; investigation, P.V.K., A.K.B., D.N.I. and V.M.Y.; resources, P.V.K. and L.V.P.; data curation, P.V.K., T.V.T. and L.V.P.; writing-original draft preparation, P.V.K. and T.V.T.; writing-review and editing, L.V.P.; visualization, P.V.K. and D.N.I.; supervision, L.V.P.; project administration, P.V.K.; funding acquisition, P.V.K. All authors have read and agreed to the published version of the manuscript.

Funding: This research was funded by the Russian Science Foundation, grant number 19-73-10122.

Institutional Review Board Statement: Not applicable.

Informed Consent Statement: Not applicable.

Data Availability Statement: Data is contained within the article.

Acknowledgments: The structural studies of compounds were carried out at the Center for Collective Use "Agidel" at the Institute of Petrochemistry and Catalysis, Russian Academy of Sciences.

Conflicts of Interest: The authors declare no conflict of interest.

Sample Availability: Samples of the compounds are not available from the authors.

\section{References}

1. Organometallic Reactions and Polymerization; Osakada, K. (Ed.) Springer-Verlag: Berlin/Heidelberg, Germany, 2014 ; p. 301. [CrossRef]

2. Nicholas, C.P. Applications of light olefin oligomerization to the production of fuels and chemicals. Appl. Cat. A Gen. 2017, 543, 82-97. [CrossRef]

3. de Klerk, A. Oligomerization. In Fischer-Tropsch Refining; de Klerk, A., Ed.; Wiley-VCH Verlag: Hoboken, NJ, USA, 2011; pp. 369-391. [CrossRef]

4. McGuinness, D.S. Olefin Oligomerization via Metallacycles: Dimerization, Trimerization, Tetramerization, and Beyond. Chem. Rev. 2011, 111, 2321-2341. [CrossRef]

5. Nifant'ev, I.; Ivchenko, P.; Tavtorkin, A.; Vinogradov, A.; Vinogradov, A. Non-traditional Ziegler-Natta Catalysis in a-Olefin Transformations: Reaction Mechanisms and Product Design. Pure Appl. Chem. 2017, 89, 1017-1032. [CrossRef]

6. Janiak, C. Metallocene and Related Catalysts for Olefin, Alkyne and Silane Dimerization and Oligomerization. Coord. Chem. Rev. 2006, 250, 66-94. [CrossRef]

7. Comyns, A.E. Encyclopedic Dictionary of Named Processes in Chemical Technology, 4th ed.; CRC Press: Boca Raton, FL, USA, 2014; p. 416. [CrossRef]

8. Harvey, B.G.; Meylemans, H.A. 1-Hexene: A Renewable C6 Platform for Full-performance Jet and Diesel fuels. Green Chem. 2014, 16, 770-776. [CrossRef]

9. Chen, E.Y.-X.; Marks, T.J. Cocatalysts for Metal-Catalyzed Olefin Polymerization: Activators, Activation Processes, and Structure-Activity Relationships. Chem. Rev. 2000, 100, 1391-1434. [CrossRef]

10. Resconi, L.; Cavallo, L.; Fait, A.; Piemontesi, F. Selectivity in Propene Polymerization with Metallocene Catalysts. Chem. Rev. 2000, 100, 1253-1346. [CrossRef] [PubMed]

11. Kaminsky, W. The Discovery of Metallocene Catalysts and Their Present State of the Art. J. Polym. Sci. A Polym. Chem. 2004, 42, 3911-3921. [CrossRef]

12. Collins, R.A.; Russell, A.F.; Mountford, P. Group 4 Metal Complexes for Homogeneous Olefin Polymerisation: A Short Tutorial Review. App. Petroch. Res. 2015, 5, 153-171. [CrossRef]


Formation of Dimers, Carbocycles, and Oligomers. J. Am. Chem. Soc. 1996, 118, 4715-4716. [CrossRef]

14. Christoffers, J.; Bergman, R.G. Zirconocene-alumoxane (1:1)—A Catalyst for the Selective Dimerization of $\alpha$-Olefins. Inorg. Chim. Acta 1998, 270, 20-27. [CrossRef]

15. Nifant'ev, I.E.; Vinogradov, A.A.; Vinogradov, A.A.; Ivchenko, P.V. Zirconocene-Catalyzed Dimerization of 1-Hexene: Two-stage Activation and Structure-Catalytic Performance Relationship. Cat. Commun. 2016, 79, 6-10. [CrossRef] 
16. Nifant'ev, I.E.; Vinogradov, A.A.; Vinogradov, A.A.; Sedov, I.V.; Dorokhov, V.G.; Lyadov, A.S.; Ivchenko, P.V. Structurally Uniform 1-Hexene, 1-Octene, and 1-Decene Oligomers: Zirconocene/MAO-Catalyzed Preparation, Characterization, and Prospects of Their Use as low-viscosity Low-temperature Oil Base Stocks. Appl. Cat. A Gen. 2018, 549, 40-50. [CrossRef]

17. Nifant'ev, I.E.; Vinogradov, A.A.; Vinogradov, A.A.; Churakov, A.V.; Bagrov, V.V.; Kashulin, I.A.; Roznyatovsky, V.A.; Grishin, Y.K.; Ivchenko, P.V. The Catalytic Behavior of Heterocenes Activated by TIBA and MMAO under a Low Al/Zr Ratios in 1-Octene Polymerization. Appl. Cat. A Gen. 2019, 571, 12-24. [CrossRef]

18. Nifant'ev, I.; Vinogradov, A.; Vinogradov, A.; Karchevsky, S.; Ivchenko, P. Experimental and Theoretical Study of ZirconoceneCatalyzed Oligomerization of 1-Octene. Polymers 2020, 12, 1590. [CrossRef] [PubMed]

19. Parfenova, L.V.; Kovyazin, P.V.; Bikmeeva, A.K. Bimetallic Zr,Zr-Hydride Complexes in Zirconocene Catalyzed Alkene Dimerization. Molecules 2020, 25, 2216. [CrossRef]

20. Parfenova, L.V.; Kovyazin, P.V.; Bikmeeva, A.K.; Palatov, E.R. Catalytic Systems Based on Cp2ZrX2 (X = Cl, H), Organoaluminum Compounds and Perfluorophenylboranes: Role of $\mathrm{Zr}, \mathrm{Zr}$ - and $\mathrm{Zr}, \mathrm{Al}-\mathrm{Hydride}$ Intermediates in Alkene Dimerization and Oligomerization. Catalysts 2021, 11, 39. [CrossRef]

21. Nifant'ev, I.; Vinogradov, A.; Vinogradov, A.; Karchevsky, S.; Ivchenko, P. Zirconocene-Catalyzed Dimerization of $\alpha$-Olefins: DFT Modeling of the Zr-Al Binuclear Reaction Mechanism. Molecules 2019, 24, 3565. [CrossRef]

22. Nifant'ev, I.; Ivchenko, P. Fair Look at Coordination Oligomerization of Higher $\alpha$-Olefins. Polymers 2020, 12, 1082. [CrossRef]

23. Parfenova, L.V.; Kovyazin, P.V.; Tyumkina, T.V.; Islamov, D.N.; Lyapina, A.R.; Karchevsky, S.G.; Ivchenko, P.V. Reactions of bimetallic Zr,Al- hydride complexes with methylaluminoxane: NMR and DFT study. J. Organomet. Chem. 2017, 851, 30-39. [CrossRef]

24. Dong, S.Q.; Mi, P.K.; Xu, S.; Zhang, J.; Zhao, R.D. Preparation and Characterization of Single-Component Poly- $\alpha$-olefin Oil Base Stocks. Energy Fuels 2019, 33, 9796-9804. [CrossRef]

25. Zhao, R.; Mi, P.; Xu, S.; Dong, S. Structure and Properties of Poly- $\alpha$-olefins Containing Quaternary Carbon Centers. ACS Omega 2020, 5, 9142-9150. [CrossRef] [PubMed]

26. Shao, H.; Gu, X.; Wang, R.; Wang, X.; Jiang, T.; Guo, X. Preparation of Lubricant Base Stocks with High Viscosity Index through 1-Decene Oligomerization Catalyzed by Alkylaluminum Chloride Promoted by Metal Chloride. Energy Fuels 2020, 34, 2214-2220. [CrossRef]

27. Parfenova, L.V.; Kovyazin, P.V.; Gabdrakhmanov, V.Z.; Istomina, G.P.; Ivchenko, P.V.; Nifant'Ev, I.E.; Khalilov, L.M.; Dzhemilev, U.M. Ligand Exchange Processes in Zirconocene Dichloride-Trimethylaluminum Bimetallic Systems and Their Catalytic Properties in Reaction with Alkenes. Dalton Trans. 2018, 47, 16918-16937. [CrossRef] [PubMed]

28. Parfenova, L.V.; Pechatkina, S.V.; Khalilov, L.M.; Dzhemilev, U.M. Mechanism of $\mathrm{Cp}_{2} \mathrm{ZrCl}_{2}$-Catalyzed Olefin Hydroalumination by Alkylalanes. Russ. Chem. Bull. 2005, 54, 316-327. [CrossRef]

29. Parfenova, L.V.; Kovyazin, P.V.; Nifant'ev, I.E.; Khalilov, L.M.; Dzhemilev, U.M. Role of Zr,Al Hydride Intermediate Structure and Dynamics in Alkene Hydroalumination with $\mathrm{XAlBu}^{\mathrm{i} 2}\left(\mathrm{X}=\mathrm{H}, \mathrm{Cl}, \mathrm{Bu}^{\mathrm{i}}\right)$, Catalyzed by $\mathrm{Zr} \eta^{5}$-Complexes. Organometallics 2015, 34, 3559-3570. [CrossRef]

30. Perdew, J.P.; Burke, K.; Ernzerhof, M. Generalized Gradient Approximation Made Simple. Phys. Rev. Lett. 1996, 77, 3865-3868. [CrossRef]

31. Laikov, D.N. Razvitiye ekonomnogo podkhoda k raschetu molekul metodom funktsionala plotnosti i yego primeneniye k resheniyu slozhnykh khimicheskikh zadach. Ph.D Thesis, Moscow State University, Moscow, Russia, 2000. (In Russian).

32. Laikov, D.N. Fast Evaluation of Density Functional Exchange-Correlation Terms Using the Expansion of the Electron Density in Auxiliary Basis Sets. Chem. Phys. Lett. 1997, 281, 151-156. [CrossRef]

33. Freidlina, R.K.; Brainina, E.M.; Nesmeyanov, A.N. The Synthesis of Mixed Pincerlike Cyclopentadienyl Compounds of Zirconium. Dokl. Acad. Nauk SSSR 1961, 138, 1369-1372.

34. Shoer, L.I.; Gell, K.I.; Schwartz, J. Mixed-Metal Hydride Complexes Containing Zr-H-Al Bridges. Synthesis and Relation to Transition-Metal-Catalyzed Reactions of Aluminum Hydrides. J. Organomet. Chem. 1977, 136, c19-c22. [CrossRef]

35. Laikov, D.N.; Ustynyuk, Y.A. PRIRODA-04: A quantum-chemical program suite. New possibilities in the study of molecular systems with the application of parallel computing. Russ. Chem. Bull. 2005, 54, 820-826. [CrossRef]

36. Ditchfield, R. Self-consistent Perturbation Theory of Diamagnetism. Mol. Phys. 1974, 27, 789-807. [CrossRef]

37. Wolinski, K.; Hinton, J.F.; Pulay, P. Efficient Implementation of the Gauge-independent Atomic Orbital Method for NMR Chemical Shift Calculations. J. Am. Chem. Soc. 1990, 112, 8251-8260. [CrossRef]

38. Frisch, M.J.; Trucks, G.W.; Schlegel, H.B.; Scuseria, G.E.; Robb, M.A.; Cheeseman, J.R.; Scalmani, G.; Barone, V.; Mennucci, B.; Petersson, G.A.; et al. Gaussian 09 Rev. D.01; Gaussian: Wallingford, CT, USA, 2009.

39. Adamo, C.; Barone, V. Toward reliable density functional methods without adjustable parameters: The PBE0 model. J. Chem. Phys. 1999, 110, 6158-6170. [CrossRef]

40. Weigend, F.; Ahlrichs, R. Balanced Basis Sets of Split Valence, Triple Zeta Valence and Quadruple Zeta Valence Quality for H to Rn: Design and Assessment of Accuracy. Phys. Chem. Chem. Phys. 2005, 7, 3297-3305. [CrossRef] [PubMed]

41. Andrae, D.; Häußermann, U.; Dolg, M.; Stoll, H.; Preuß, H. Energy-adjustedab Initio Pseudopotentials for the Second and Third Row Transition Elements. Theor. Chim. Acta 1990, 77, 123-141. [CrossRef]

42. Grimme, S.; Ehrlich, S.; Goerigk, L. Effect of the Damping Function in Dispersion Corrected Density Functional Theory. J. Comput. Chem. 2011, 32, 1456-1465. [CrossRef] 
43. Rocchigiani, L.; Fernandez-Cestau, J.; Chambrier, I.; Hrobárik, P.; Bochmann, M. Unlocking Structural Diversity in Gold(III) Hydrides: Unexpected Interplay of cis/trans-Influence on Stability, Insertion Chemistry, and NMR Chemical Shifts. J. Am. Chem. Soc. 2018, 140, 8287-8302. [CrossRef]

44. Barone, V.; Cossi, M. Quantum Calculation of Molecular Energies and Energy Gradients in Solution by a Conductor Solvent Model. J. Phys. Chem. A 1998, 102, 1995-2001. [CrossRef]

45. Cossi, M.; Rega, N.; Scalmani, G.; Barone, V. Energies, structures, and electronic properties of molecules in solution with the C-PCM solvation model. J. Comput. Chem. 2003, 24, 669-681. [CrossRef]

46. Zhurko, G.A.; Zhurko, D.A. ChemCraft 1.6; Informer Technologies, Inc.: Roseau, Dominica, 2009. 